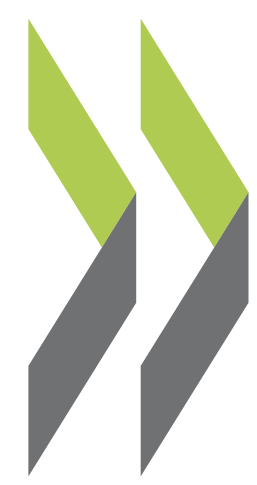

OECD Economics Department Working Papers No. 1556

Public policy reforms to further improve Portuguese export Ben Westmore, performance 


\section{PUBLIC POLICY REFORMS TO FURTHER IMPROVE PORTUGUESE EXPORT PERFORMANCE}

\section{ECONOMIC DEPARTMENT WORKING PAPER No. 1556}

\section{By Ben Westmore and Paula Adamczyk}

OECD Working Papers should not be reported as representing the official views of the OECD or of its member countries. The opinions expressed and arguments employed are those of the author(s).

Authorised for publication by Isabell Koske, Deputy Director, Country Studies Branch, Economics Department.

All Economics Department Working Papers are available at www.oecd.org/eco/workingpapers.

JT03449164 
OECD Working Papers should not be reported as representing the official views of the OECD or of its member countries. The opinions expressed and arguments employed are those of the author(s).

Working Papers describe preliminary results or research in progress by the author(s) and are published to stimulate discussion on a broad range of issues on which the OECD works.

Comments on Working Papers are welcomed, and may be sent to OECD Economics Department, 2 rue André Pascal, 75775 Paris Cedex 16, France, or by e-mail to eco.contact@oecd.org.

All Economics Department Working Papers are available at www.oecd.org/eco/workingpapers.

This document and any map included herein are without prejudice to the status of or sovereignty over any territory, to the delimitation of international frontiers and boundaries and to the name of any territory, city or area.

The statistical data for Israel are supplied by and under the responsibility of the relevant Israeli authorities. The use of such data by the OECD is without prejudice to the status of the Golan Heights, East Jerusalem and Israeli settlements in the West Bank under the terms of international law.

On 25 May 2018, the OECD Council invited Colombia to become a Member. At the time of publication the deposit of Colombia's instrument of accession to the OECD Convention was pending and therefore Colombia does not appear in the list of OECD Members and is not included in the OECD zone aggregates.

\section{(C) OECD (2019)}

You can copy, download or print OECD content for your own use, and you can include excerpts from OECD publications, databases and multimedia products in your own documents, presentations, blogs, websites and teaching materials, provided that suitable acknowledgment of OECD as source and copyright owner is given. All requests for commercial use and translation rights should be submitted to rights@oecd.org 
ABSTRACT/RÉSUMÉ

\section{Public policy reforms to further improve Portuguese export performance}

Portugal's export performance over the past decade has been impressive, helping to reduce external imbalances. This partly owed to a sequence of structural reforms that benefited the productivity of the export sector and led to an increase in its size. Nonetheless, exports as a share of GDP and the stock of foreign direct investment remain below that of other comparable small European economies. Further shifting the orientation of the economy to the external sector is vital for Portugal given the strong link between trade openness and GDP per capita. To do this, policymakers must ensure that policy settings incentivise exporting firms to expand and improve their competitiveness, both through lower price and improved quality. For example, regulatory barriers that reduce competition in professional services should be lowered to improve the cost and quality of intermediate inputs. Increasing the efficiency of domestic infrastructure is also key, especially through competition-enhancing reforms to the port sector. To further differentiate and improve Portuguese export products, skills in the business sector need to be enhanced through better-targeted lifelong learning opportunities. At the same time, there is a need to focus innovation policies on raising the participation of small and medium enterprises in innovative activities.

This Working Paper relates to the 2019 OECD Economic Survey of Portugal (http://www.oecd.org/economy/surveys/portugal-economic-snapshot/)

JEL classification: F43, G38, H25, O31, O43.

Keywords: export performance, foreign direct investment, competitiveness, regulatory reforms, infrastructure, lifelong learning, innovation.

$* * * * * * * * * * * * * * * * * * * * * * * * * * * * * * * * * * * * * * * *$

\section{Réformes des politiques publiques pour améliorer encore les résultats à l'exportation du Portugal}

Les exportations du Portugal au cours des dix dernières années ont été impressionnantes et ont permis de réduire les déséquilibres extérieurs. Cela est dû en partie à une série de réformes structurelles qui ont profité à la productivité du secteur exportateur et ont conduit à une augmentation de sa taille. Néanmoins, les exportations en pourcentage du PIB et le stock d'investissements étrangers directs restent inférieurs à ceux d'autres petites économies européennes comparables. Il est vital pour le Portugal de modifier l'orientation de l'économie vers le secteur extérieur, étant donné le lien étroit qui existe entre l'ouverture des échanges et le PIB par habitant. Pour ce faire, les décideurs doivent veiller à ce que les cadres politiques incitent les entreprises exportatrices à accroître et à améliorer leur compétitivité, à la fois par des prix plus bas et une qualité améliorée. Par exemple, les obstacles réglementaires qui réduisent la concurrence dans les services professionnels devraient être réduits pour améliorer le prix et la qualité des intrants intermédiaires. L'augmentation de l'efficacité des infrastructures nationales est également essentielle, notamment par le biais de réformes du secteur portuaire renforçant la concurrence. Pour différencier davantage et améliorer les produits d'exportation portugais, il est nécessaire de renforcer les compétences du secteur des entreprises grâce à des possibilités d'apprentissage tout au long de la vie mieux ciblées. Dans le même temps, il est nécessaire de centrer les politiques d'innovation sur l'augmentation de la participation des petites et moyennes entreprises aux activités innovantes.

Ce document de travail porte sur l'Étude économique du Portugal 2019 de l'OCDE

(http://www.oecd.org/fr/economie/etudes/portugal-en-un-coup-d-oeil/)

Classification JEL : F43, G38, H25, O31, O43.

Mots-clés : résultats à l'exportation, investissement direct étranger, compétitivité, réformes réglementaires, infrastructures, apprentissage tout au long de la vie, innovation. 


\section{Table of contents}

Public policy reforms to further improve Portuguese export performance........................................ 6

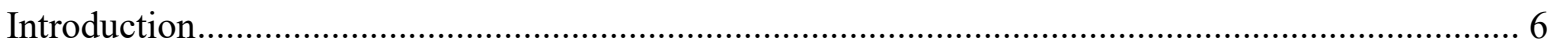

Improving the framework policies for high-potential businesses .................................................... 14

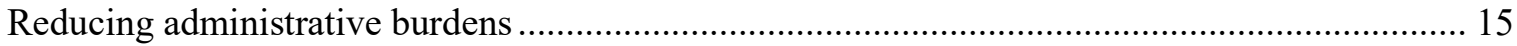

Reforming other policy settings that discourage or hamper firm growth.................................... 18

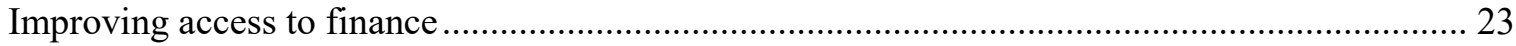

Ensuring domestic infrastructure promotes better export performance ........................................... 25

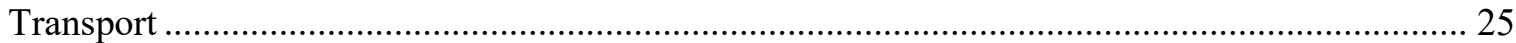

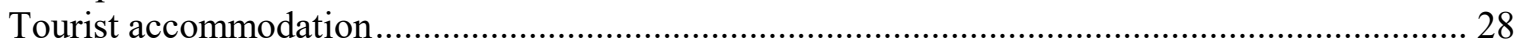

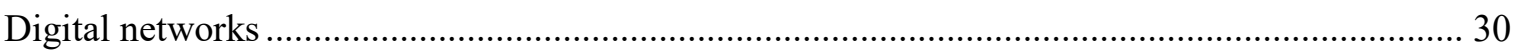

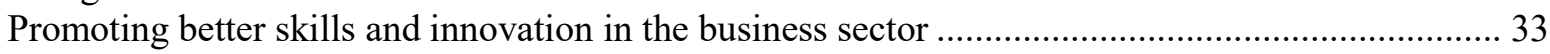

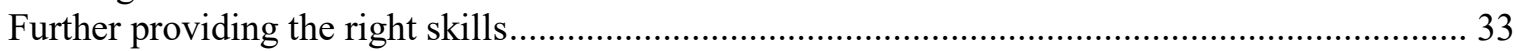

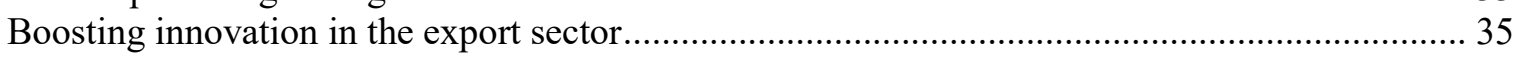

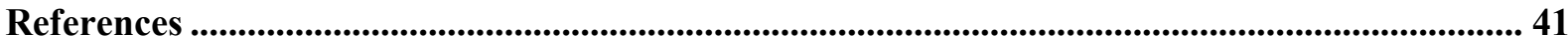

\section{Tables}

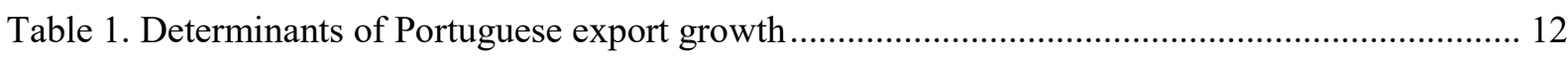

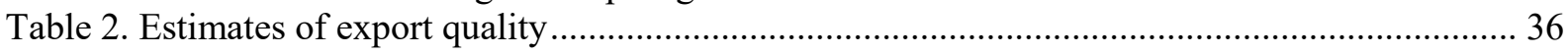

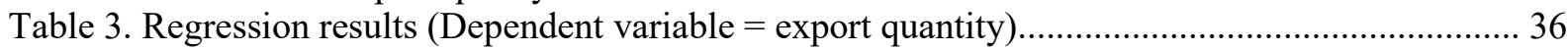

Figures

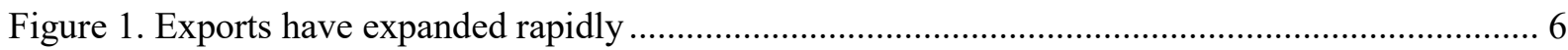

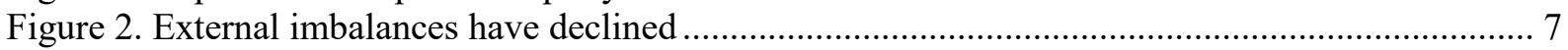

Figure 3. Tourism has accounted for a large share of recent export growth ........................................ 7

Figure 4. The United Kingdom has become an increasingly important origin of tourists ..................... 8

Figure 5. Increased security risk in some destinations appears to have discouraged some tourists ....... 9

Figure 6. Both foreign demand for Portuguese exports and domestic demand have been weak ......... 10

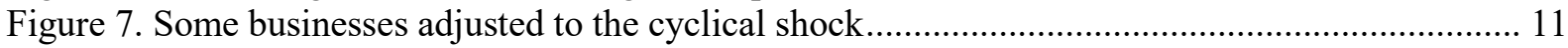

Figure 8. Export intensity is lower than in other small European countries........................................ 13

Figure 9. A declining share of exporters are young firms ............................................................. 14

Figure 10. There is scope for government reforms to support firm growth ....................................... 15

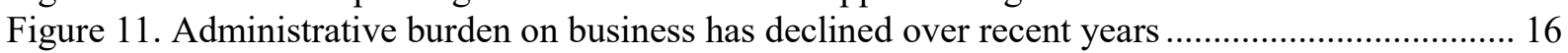

Figure 12. Tax administration takes significant time for businesses ................................................... 18

Figure 13. Portuguese R\&D tax incentives are more beneficial for profitable firms .......................... 20

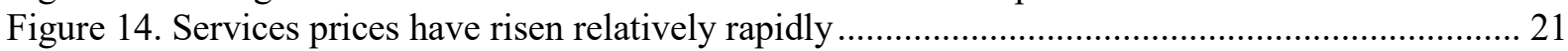

Figure 15. Restrictions on trade in some professional services reduce competition ............................. 21

Figure 16. Inefficient customs processes may be exacerbated by barriers to the customs broker

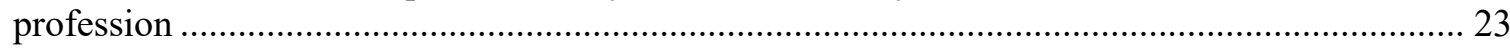

Figure 17. Borrowing costs for Portuguese firms have declined rapidly ............................................ 24

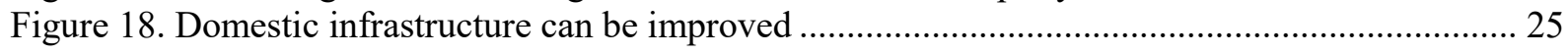

Figure 19. Rising tourist demand has pushed-up accommodation prices ............................................ 29

Figure 20. Broadband access is widespread but not many firms sell online ........................................ 31 
Figure 21. Few businesses have integrated digital technologies into their operations .......................... 31

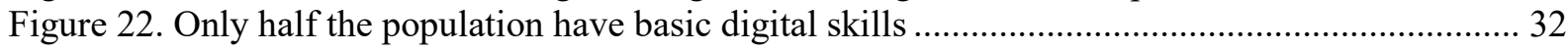

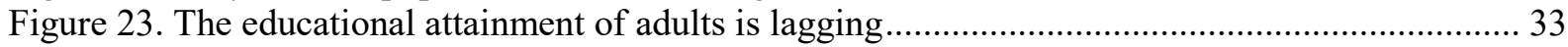

Figure 24. Participation in lifelong learning opportunities is low ...................................................... 34

Figure 25. Professional management in the business sector is relatively rare ..................................... 35

Figure 26. The export product mix is relatively mature ..................................................................... 37

Figure 27. Research intensity and innovation output in the business sector are low .......................... 37

Figure 28. Collaborative research activities are limited, especially for small firms ............................. 38

\section{Boxes}

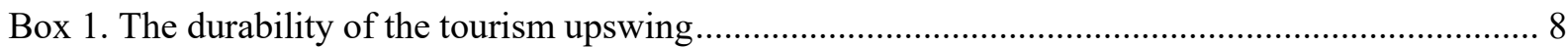

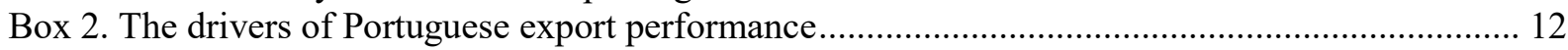

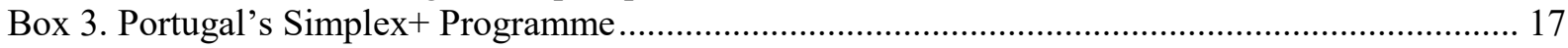

Box 4. Portuguese National Initiative on Digital Competencies 2030 (INCoDe.2030) ....................... 32

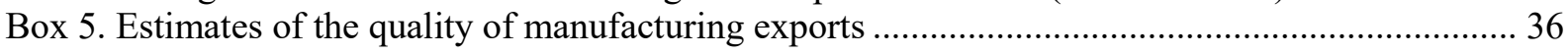

Box 6. Fostering innovation collaboration through Programa Interface ............................................ 38 


\title{
Public policy reforms to further improve Portuguese export performance
}

\author{
By Ben Westmore and Paula Adamczyk ${ }^{1}$
}

\section{Introduction}

Portugal's export performance has been impressive, sustaining the economy through years of weak domestic demand in the wake of the banking and sovereign debt crisis. Between 2009 and 2017, the volume of exports expanded by over 60\% (compared to around $20 \%$ during the 2001-2009 period), causing the share of exports in Portugal's GDP to rise from around $30 \%$ to $44 \%$ during a period of weak economic growth (Figure 1, Panel A). This has been associated with an expansion in exports' market share, an indication of improved competitiveness (Figure 1, Panel B). Inward foreign direct investment as a percentage of GDP also trended higher over the period.

Figure 1. Exports have expanded rapidly

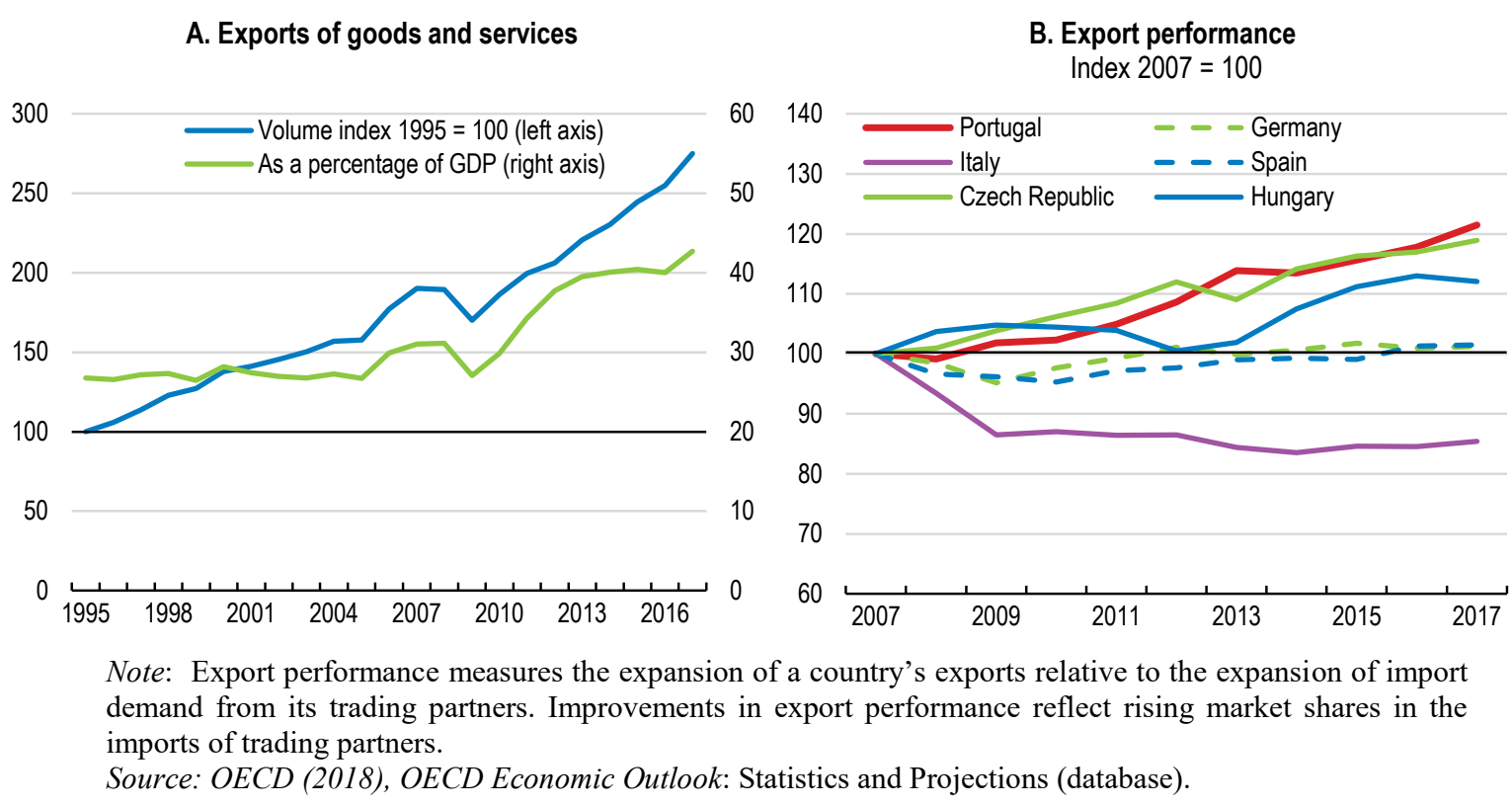

The strong performance of the external sector has helped Portugal begin to reverse external imbalances (Figure 2). Such imbalances built up prior to the financial crisis as export competitiveness stagnated and private debt for consumption, housing and construction

\footnotetext{
${ }^{1}$ Ben Westmore (ben.westmore@oecd.org) and Paula Adamczyk (paula.adamczyk@oecd.org) are members of the OECD Economics Department. The authors would like to thank Alvaro Pereira, Pierre Beynet, Yosuke Jin, Thomas Chalaux, Bert Brys, Priscilla Fialho and Ania Thiemann for valuable discussions and feedback on earlier drafts. The paper also benefitted from the comments of officials in the Portuguese government and by members of the OECD Economic and Development Review Committee. The text incorporates available information at 18 February 2019; subsequent policy and other developments are not reflected.
} 
purposes grew rapidly. External liabilities narrowed from their peak in 2012 of just below $250 \%$ of GDP to around $210 \%$ by the end of 2017 .

Figure 2. External imbalances have declined

Balance of payments, percentage of GDP

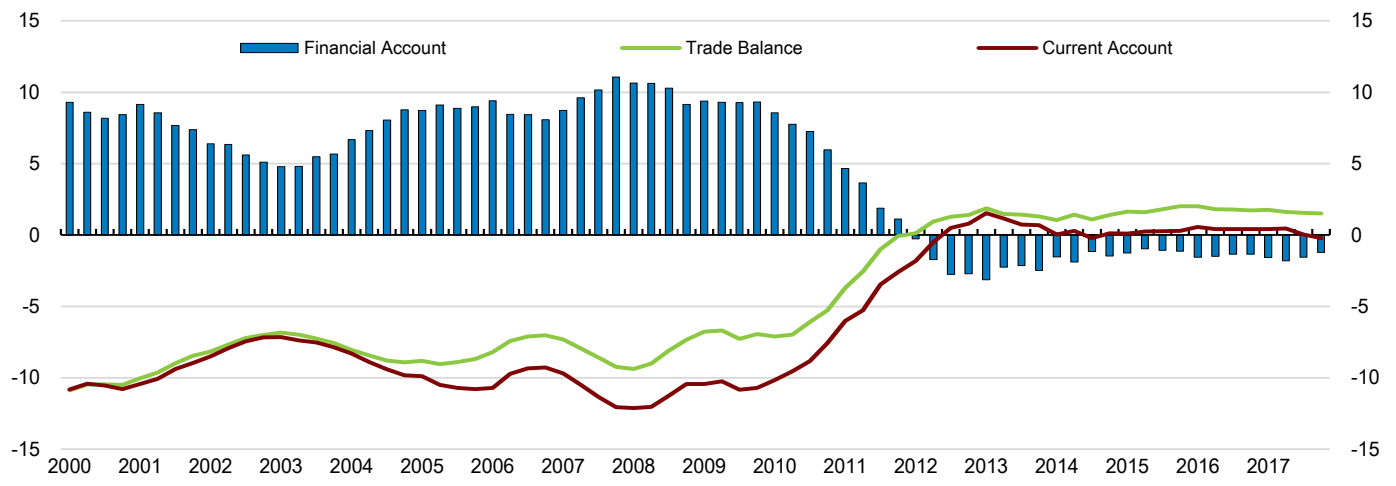

Source: Eurostat.

Part of the improvement in exports has been due to strong growth in travel and tourism. Over one-fifth of the growth in exports between 2009 and 2017 was directly attributable to the tourism industry, with other closely related sectors such as transportation also having a strong positive effect (Figure 3 ). The growth in tourism has been particularly marked since 2013. This has coincided with an increase in the supply of tourist accommodation (IMF, 2017) and in the capacity of low-cost airlines flying to Portugal (European Commission, 2018). An escalation of perceived security risks in competing markets has been a contributing factor to the surge in tourists, though one that may prove transitory (Box 1). However, the boom in tourism has only been part of the story. A number of manufacturing sectors also contributed strongly to Portugal's export growth in the post-crisis period. These included minerals, chemicals, machinery and agri-food (Figure 3).

Figure 3. Tourism has accounted for a large share of recent export growth

Contribution to total export growth over the 2009-2017 period, percentage

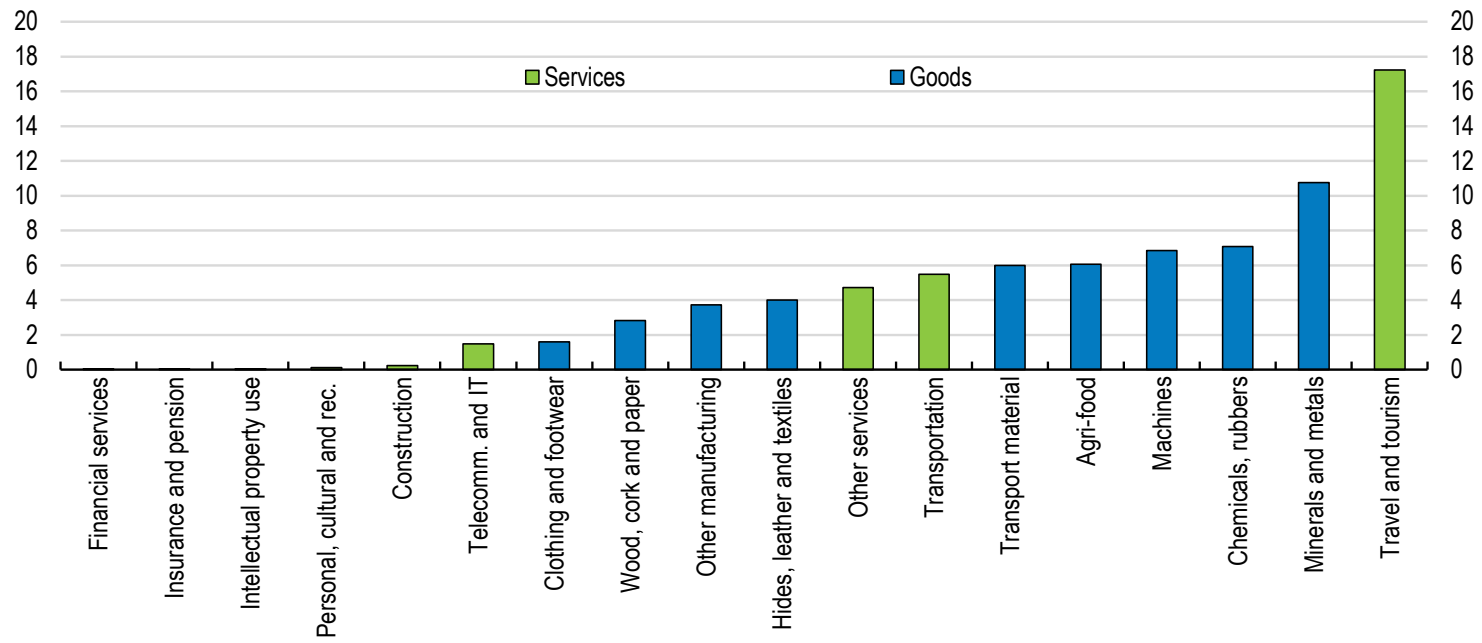

Source: Bank of Portugal, OECD calculations. 


\section{Box 1. The durability of the tourism upswing}

Some signs of diversification in Portugal's tourism sector bode well for its durability over the medium-term. However, a segment of tourist flows may have become more exposed to sudden reversals given that it has been motivated by security concerns in competitor markets that could fade.

The number of overnight tourists visiting Portugal rose 64\% between 2009 and 2016. Since 2009, the age profile of tourists in Portugal has gradually broadened beyond the core 25-64 age group. The proportion of all tourists aged above 64 rose from $9 \%$ to $17 \%$ between 2008 and 2016. There have also been signs of greater geographic diversification of tourist flows within Portugal, with the proportion of tourists destined for the three main tourist regions (Algarve, Northern and Central Portugal) having slightly declined from $73 \%$ to $70 \%$ over the $2008-16$ period. The share of local tourists also declined over the period, with the majority of tourists now being non-residents.

At the same time, the origin of overseas tourists has become slightly less concentrated. Overseas visitors from Portugal's top four country markets fell from 53\% to 50\% between 2013 and 2017. Since 2009, there was a notable increase in visitors from the United Kingdom, causing British visitors to overtake Spaniards as the main visitors (Figure 4).

Figure 4. The United Kingdom has become an increasingly important origin of tourists

Number of tourists to Portugal by origin market

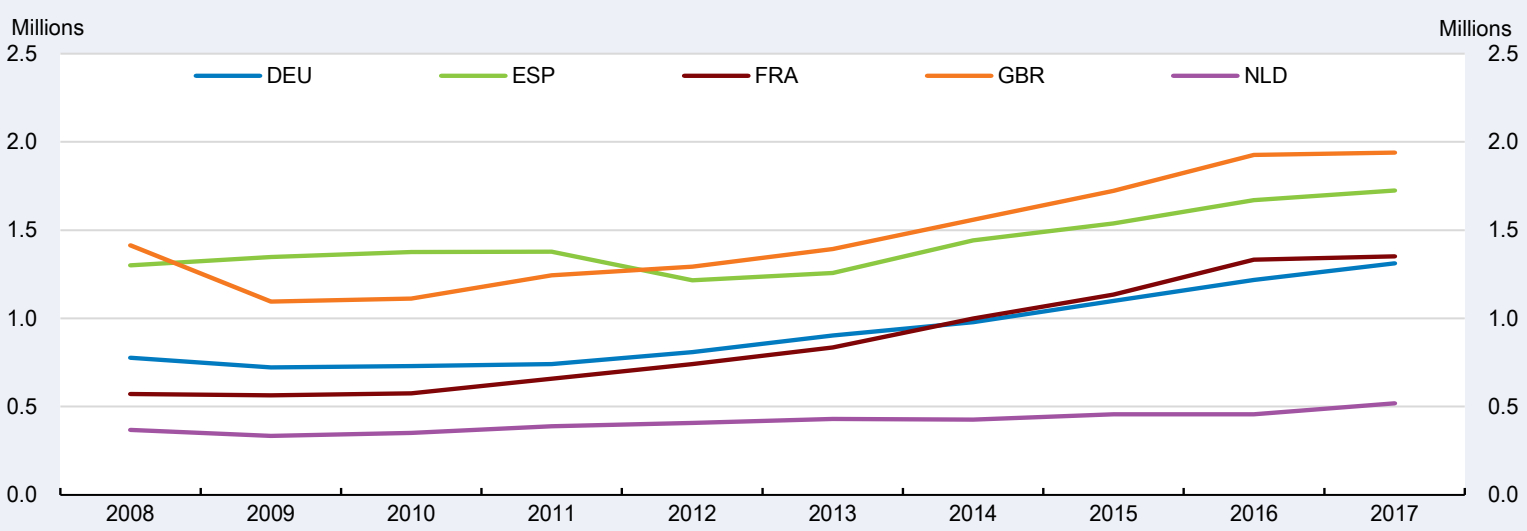

Source: OECD (2018) OECD Tourism Trends and Policies; Statistics Portugal.

One factor cited for the pick-up in tourist flows to Portugal has been heightened perceptions of security risk in competitor markets (Economist Intelligence Unit, 2018). Focusing on German tourists in the early 2000s, (Ahlfeldt, Franke and Maennig, 2015) highlighted the potential for terrorist activities in a destination country to prompt tourists to substitute towards other similar locations they perceive to be more safe. Data on the destination of outbound tourists from the United Kingdom does signal that recent tourist flows have been sensitive to terrorist events (Figure 5). 


\section{Figure 5. Increased security risk in some destinations appears} to have discouraged some tourists

Change in tourist visits by UK nationals, 2010-2016

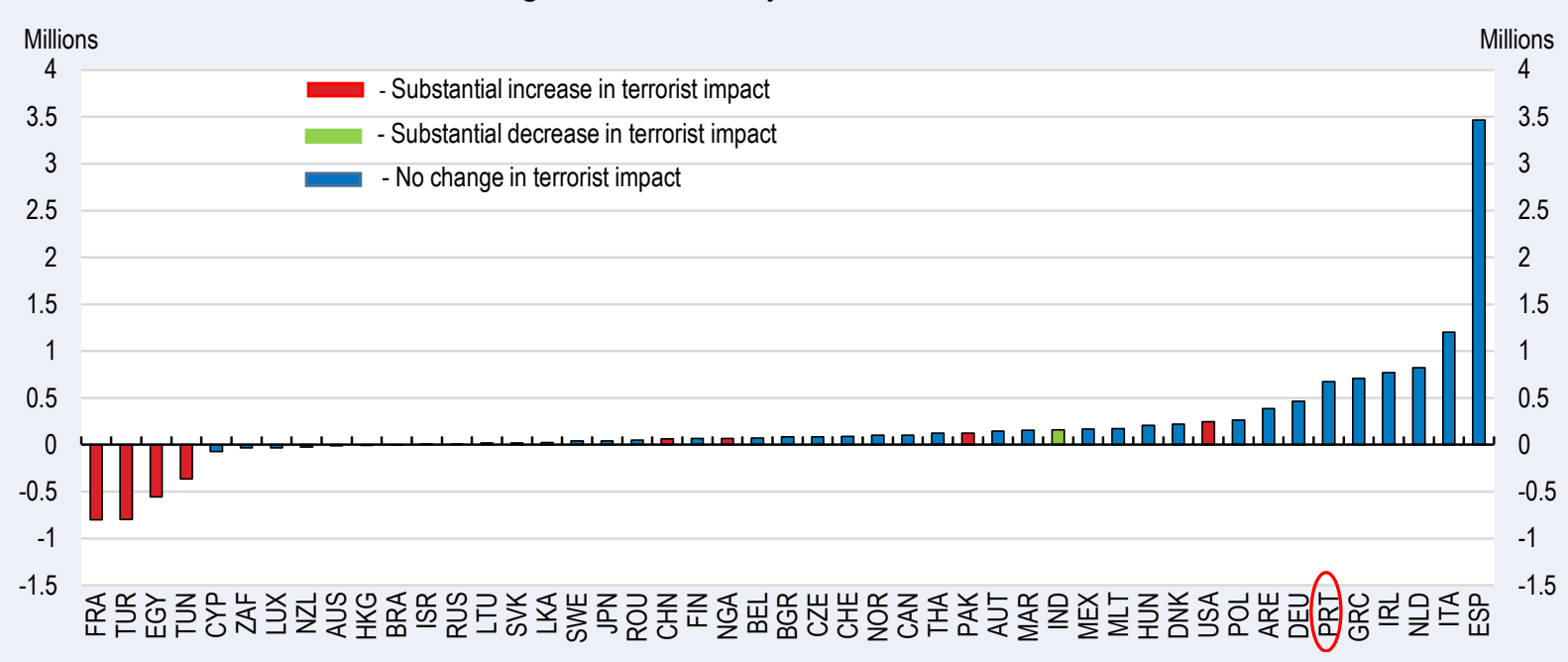

Note: A "substantial increase in terrorist impact" is defined as an increase of at least $30 \%$ in the number of terrorist-related deaths in the country in the 2011-2016 period compared with the 2005-2010 period and an absolute increase of at least 100 terrorist-related deaths. Similarly, a "substantial decrease in terrorist impact" is defined as at least a $30 \%$ decline in terrorist related deaths and an absolute decrease of at least 100 terroristrelated deaths over the same period.

Source: Office for National Statistics, Global Terrorism Database.

The decline in United Kingdom tourists between 2010 and 2016 to countries that faced an increased impact of terrorism such as France, Turkey, Egypt and Tunisia coincided with a rise in travellers to Portugal and some other southern European countries such as Spain, Italy and Greece.

Given these patterns, the capacity for a decline or stabilisation in perceived security risk elsewhere could lead some tourist flows that were redirected to Portugal to reverse. One illustrative historical example is the recent case of Turkey. There was a notable drop in tourists from the United Kingdom to Turkey in 2012 and 2013, coinciding with a substantial increase in the terrorist activities of the Kurdistan Workers Party. However, an appeasement in such activity over the following few years was accompanied by a stabilisation of tourist flows in 2014 before an increase of visitors by more than $10 \%$ in 2015. It is very difficult to generalise the impacts on tourist arrivals across heterogeneous security threats. Nevertheless, the Portuguese authorities should plan for the possibility that some of the recent boom in tourism could be unwound.

As part of the government's Tourism Strategy 2027, diversification, innovation and training in the tourism sector have been identified as some of the major priorities. The strategy embodies a long-term vision, accompanied by targets related to economic, environmental and social outcomes.

Focusing on manufacturing exports, while growth in foreign demand in those product markets in which Portugal is specialised was modest (Figure 6, Panel A), comparatively weak domestic demand growth contributed to more Portuguese firms increasing their 
efforts to export (Esteves and Rua, 2015). At the aggregate level, the negative relationship between domestic demand and exports appears to have been especially strong in the 201013 period (Figure 6, Panel B).

Figure 6. Both foreign demand for Portuguese exports and domestic demand have been weak

A. Rank correlation between revealed comparative advantage index and world trade growth, 2009-2015

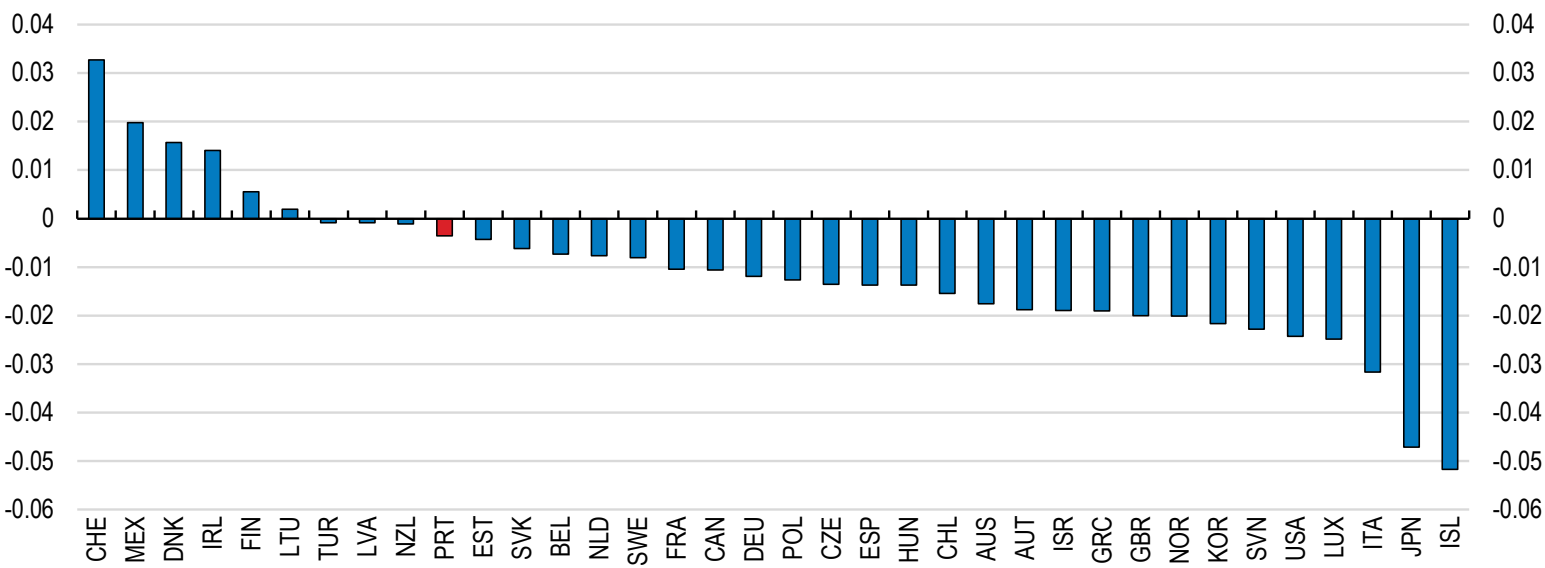

B. Components of aggregate demand, average annual growth (\%)

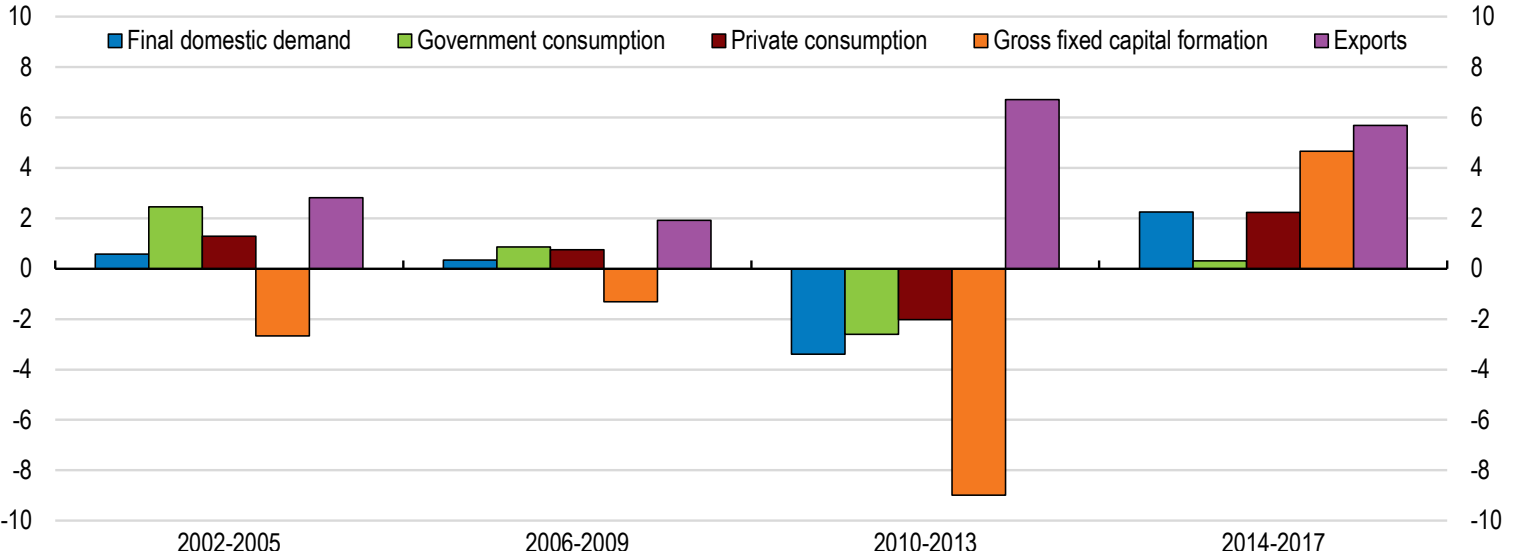

Note: In Panel A, the degree of specialisation in a product is proxied by the revealed symmetric comparative advantage index outlined by (Dalum, Laursen and Villumsen, 1998).

Source: OECD (2018), OECD Economic Outlook: Statistics Projections (database), Araujo, Chalaux and Haugh (2018).

The post-crisis period was characterised by a slightly larger proportion of firms beginning to export (Figure 7, Panel A) and increased integration with global value chains (Figure 7, Panel B). Manufacturing exporters became specialised in a slightly broader set of product categories (Figure 7, Panel C) and notably improved the quality of export products (see Box 5 further below). Businesses increasingly cut labour costs and adopted more flexible price-setting behaviour (Martins, 2016). Indeed, despite sluggish productivity growth, Portuguese export prices relative to its competitors declined by around $6 \%$ in the 2009 2017 period (Figure 7, Panel D). The results of the regression analysis described in Box 2 suggest that both improvements in export quality and the decline in relative export prices positively impacted Portuguese exports through the period. 
The ability for the business sector to become more outward oriented and undertake the necessary structural adjustments partly owed to a sequence of reforms. These included reductions in administrative burdens on businesses (discussed further below) and the elimination of policy barriers to foreign direct investment.

Figure 7. Some businesses adjusted to the cyclical shock

A. Exporters as a percentage of total enterprises

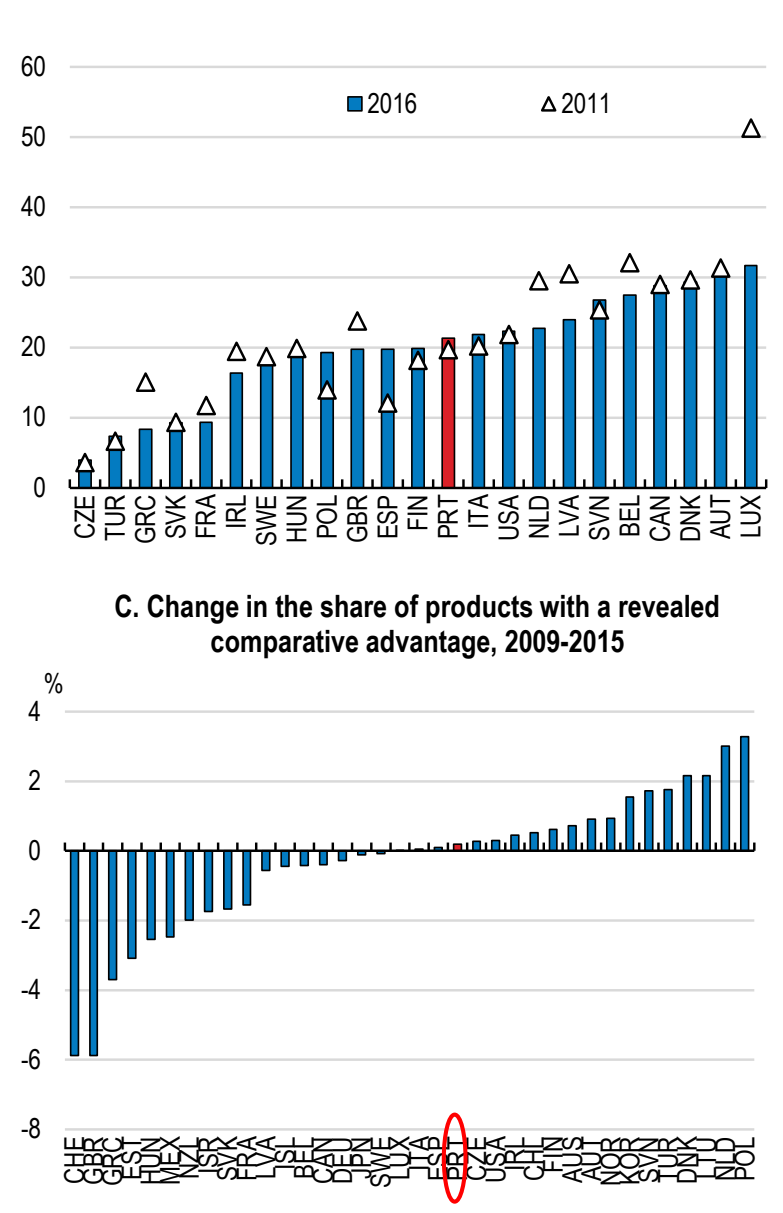

B. Backward and forward participation in global value chains

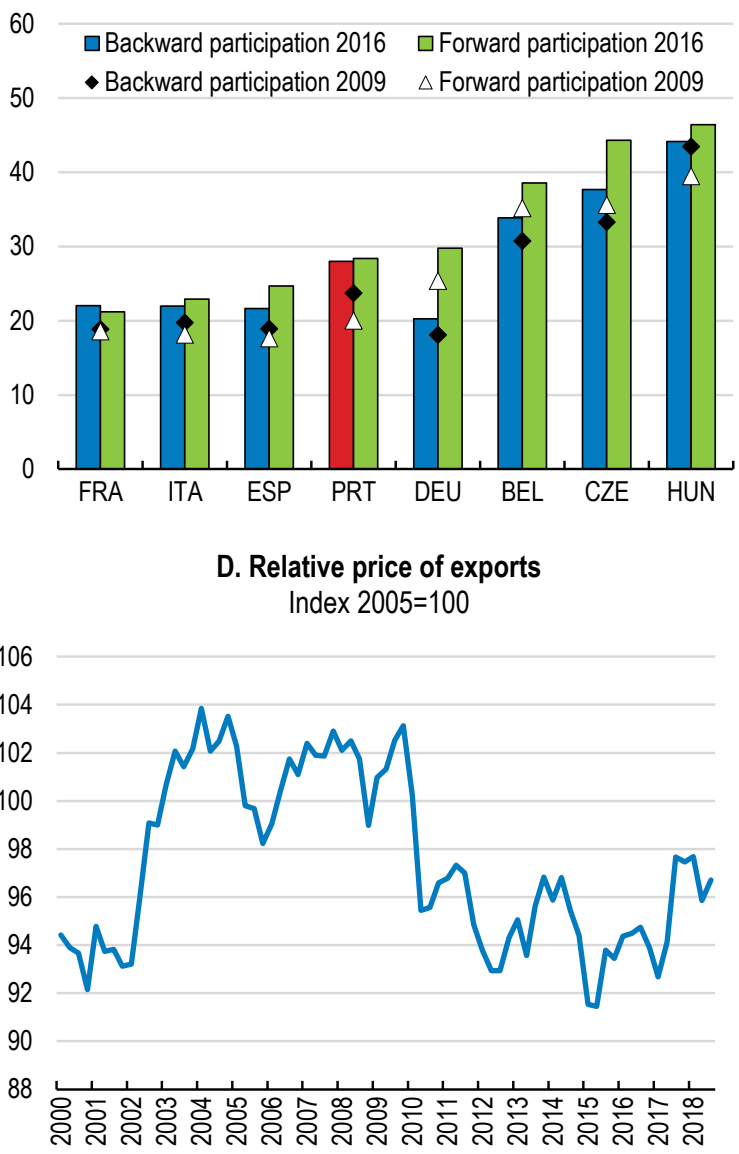

Note: In Panel A, data for Luxembourg refers to 2015, and for Turkey, United Kingdom and United States refer to 2014. In Panel B, backward participation is measured as the foreign value added share of gross exports for each country. In Panel $\mathrm{C}$, the share of products is the number of products with a revealed symmetric comparative advantage on the total number of products exported by each country. A country has a revealed comparative advantage when the export share of product $\mathrm{p}$ in their export basket is higher than the corresponding share of product $\mathrm{p}$ in world exports. The data underlying Panel $\mathrm{C}$ are calculated using six-digit harmonised system product level that comprises 4350 different products. Forward participation is measured as the domestic value added share of foreign final demand. In Panel D, a trade-weighted measure of Portuguese export prices relative to those of competitor economies is presented. Further explanation of the index can be found in (Morin and Schwellnus, 2014).

Source: UN Comtrade database, OECD Structural Business Statistics, OECD Trade by Enterprise Class Database, OECD Compendium of Productivity Indicators, Araujo, Chalaux and Haugh (2018), OECD calculations based on Trade in Value Added (TiVA) Database and OECD Economic Outlook (database). 


\section{Box 2. The drivers of Portuguese export performance}

To explore the drivers of Portuguese export performance, a regression analysis was undertaken with the dependent variable being the growth in Portuguese exports over the 1995-2016 period. The analysis was performed using highly disaggregated product-level data (HS 6-digit level), which provided a large enough dataset to perform country-specific time-series analysis.

Explanatory variables include world demand, export product quality, relative export prices (those presented in Figure 7, Panel D) and domestic demand. Data are taken from various sources. For the dependent variable, export values at the 6-digit product-level are from the UN Comtrade Database. Export quality is proxied by an indicator of unit values at the 6digit product-level from the CEPII-BACI database. This measure of export quality is also used in the analysis of Araujo, Chalaux and Haugh (2018).

Table 1. Determinants of Portuguese export growth

Dependent variable $=\Delta \ln ($ exports $)$

\begin{tabular}{|c|c|c|c|}
\hline EXPLANATORY & (1) & (2) & (3) \\
\hline VARIABLES & Model 1 & Model 2 & Model 3 \\
\hline \multirow[t]{2}{*}{$\Delta \ln ($ exports(-1)) } & $-0.25^{\star \star \star}$ & $-0.25^{\star \star \star}$ & $-0.25^{\star \star \star}$ \\
\hline & $(0.00)$ & $(0.00)$ & $(0.00)$ \\
\hline \multirow[t]{2}{*}{$\Delta \ln ($ world demand) } & $0.23^{\star * *}$ & $0.23^{\star * *}$ & $0.23^{\star \star \star}$ \\
\hline & $(0.03)$ & $(0.03)$ & $(0.03)$ \\
\hline \multirow[t]{2}{*}{$\Delta \ln ($ export quality) } & $0.05^{\star * *}$ & $0.05^{* * *}$ & $0.05^{\star * *}$ \\
\hline & $(0.01)$ & $(0.01)$ & $(0.01)$ \\
\hline \multirow[t]{2}{*}{$\Delta \ln ($ relative export prices $(-1))$} & & $-3.06^{\star \star *}$ & \\
\hline & & $(0.68)$ & \\
\hline \multirow[t]{2}{*}{$\Delta \mathrm{ln}($ domestic demand $(-1))$} & & & $-8.04^{* * *}$ \\
\hline & & & $(1.79)$ \\
\hline \multirow[t]{2}{*}{ Constant } & $-0.07^{\star \star \star}$ & $-0.17^{\star \star \star}$ & $0.09^{*}$ \\
\hline & $(0.02)$ & $(0.02)$ & $(0.05)$ \\
\hline Observations & 48,305 & 48,305 & 48,305 \\
\hline
\end{tabular}

Note: Robust standard errors are in parentheses with $* * * \mathrm{p}<0.01, * * \mathrm{p}<0.05,{ }^{*} \mathrm{p}<0.1$. "In" refers to the natural $\log$ and " $(-1)$ " refers to the lagged value of the variable.

The regression results presented in Table 1 suggest that:

- Portuguese export growth was positively associated with export product quality and world demand.

- Portuguese export growth had a negative relationship with changes in relative export prices and domestic demand.

Based on these regression results, no one single factor can be identified as the overriding reason for Portugal strongly increasing its exports since 2009. While an improvement in price competitiveness played a role, the majority of the increase in exports appears to have been explained by other factors (for further discussion, see Adamczyk and Westmore, 2019). 
Despite the rise in Portugal's economic openness over the post-crisis period, exports as a share of GDP and the stock of foreign direct investment remain below that of other comparable small European economies (Figure 8). Associated with this, participation in global value chains also remains low relative to these countries (Figure 7, Panel B). Ensuring that public policy settings promote further growth in the export sector is important given the strong link between trade openness and GDP per capita (OECD, 2018a). Further shifting the orientation of the economy to the external sector may be especially vital for Portugal given rapid population ageing will provide a headwind to future domestic demand growth. Such a transition will also help reduce the high external imbalances that continue to exist and heighten the fragility of the economy.

Figure 8. Export intensity is lower than in other small European countries

As a percentage of GDP, 2017 or latest available year

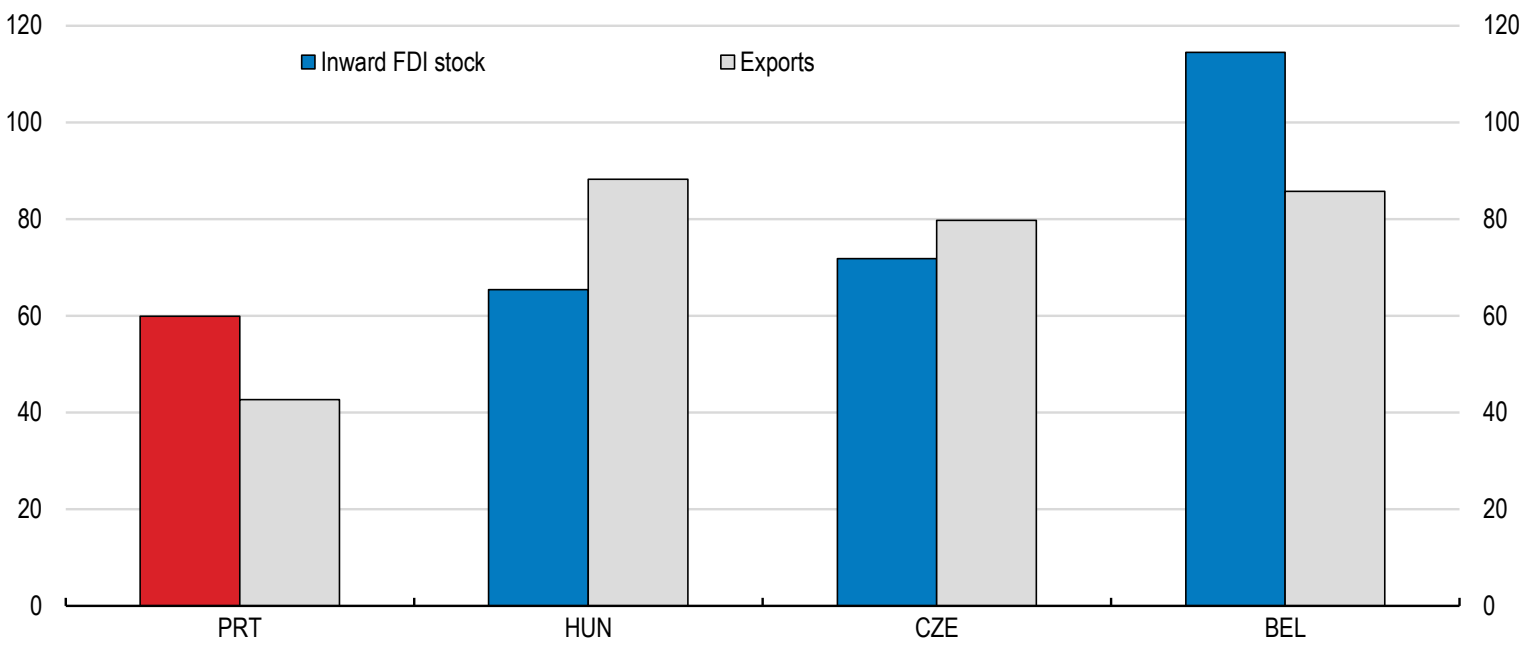

Source: OECD (2018), Trade in goods and services (indicator); OECD (2018), FDI stocks (indicator).

The need to further improve export performance is recognised by the government. As part of the Internacionalizar programme, the authorities are aiming to raise the number of exporting small and medium enterprises (SMEs) and increase the overall value of exports to $50 \%$ of GDP by 2025 . Over the medium-term, a more ambitious target is achievable, provided that sound economic policy encourages the necessary further structural adjustments in the economy and that the tourism sector continues to thrive.

A host of policy dimensions are key for promoting future export growth. Firstly, more firms need to be encouraged to export through policy settings that enable them to grow their businesses. Regulatory policies calibrated to allow and incentivise firms to expand must be complemented by a financial sector that efficiently allocates funding to high potential firms. Competitiveness and the attractiveness of the country for foreign direct investment can also be improved through policies that better support the efficiency of domestic transport, housing and digital infrastructure. At the same time, ensuring the population is accumulating useful skills and promoting innovation in the export sector will help further differentiate Portuguese products, promote productivity growth and increase the export value added accruing to the Portuguese economy. 


\section{Improving the framework policies for high-potential businesses}

Framework conditions that support an adaptable industrial structure enable firms to enter and exit markets in response to changing market conditions and grow unimpeded if they succeed. Such an environment both facilitates a greater share of firms becoming exporters and their ability to raise output if needed. With consumer preferences and technological progress evolving rapidly, such agility is particularly important for a small open economy like Portugal. To the extent that the expansion of high potential firms is facilitated by the reallocation of resources from less productive businesses, aggregate productivity of the export sector can benefit and cost competitiveness improve. Concomitantly, policy settings that foster favourable business dynamics can boost productivity growth in the non-tradable sector, reducing the costs to exporters of locally-sourced intermediate inputs.

Firm-level analysis from a census of Portuguese firms suggests that market entrants tend to have relatively high productivity growth compared to incumbent firms (OECD, 2017a). To the extent that firm entry enhances competitive pressures, new firms also increase the probability of other firms exporting (Correia and Gouveia, 2016). There is evidence that more productive firms increased their market share. Nevertheless, young firms played less of a role in the Portuguese manufacturing export sector in 2016 than in the lead up to the crisis (Figure 9).

Figure 9. A declining share of exporters are young firms

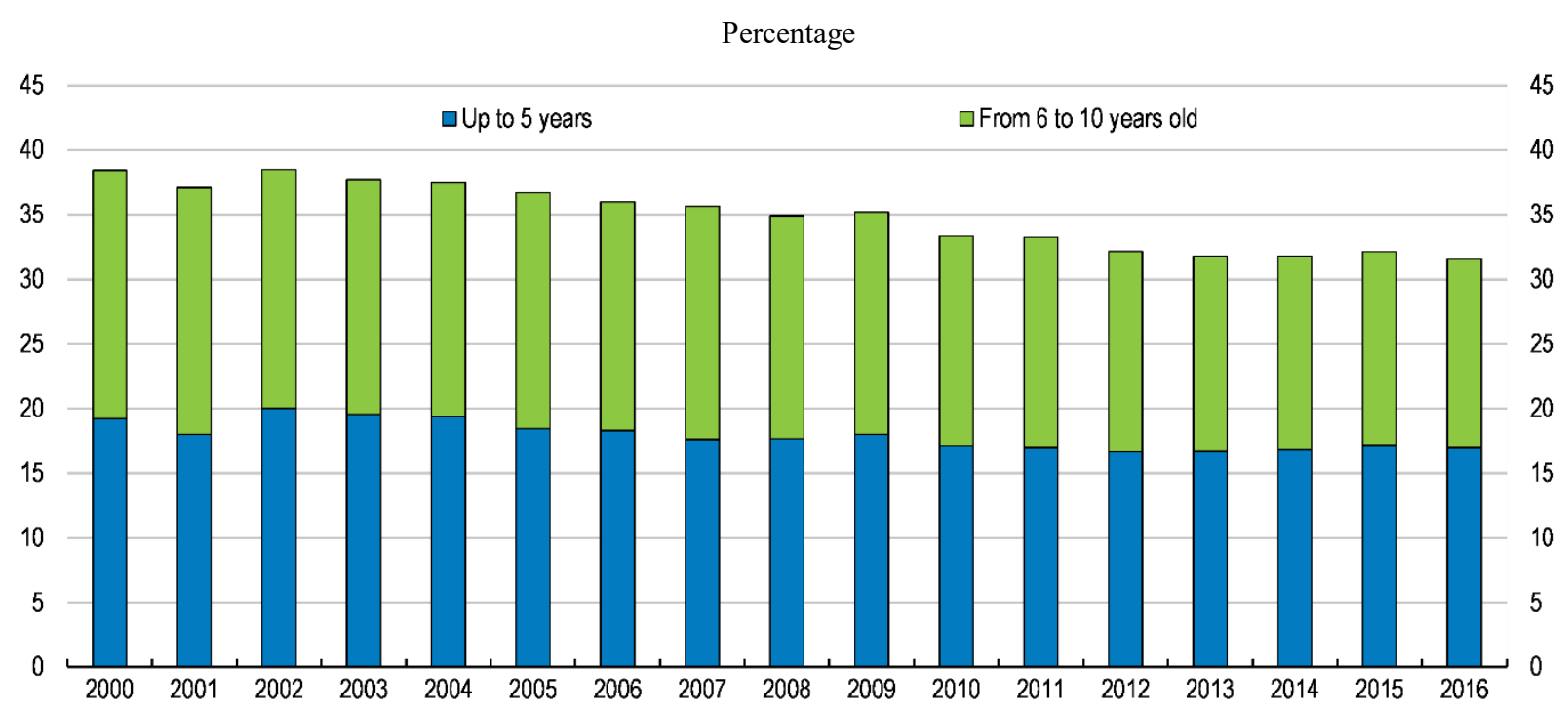

Source: OECD calculations based on the Comercio Internacional and Quadros de Pessoal datasets obtained from Statistics Portugal.

New Portuguese firms also tend to remain small, leading to a low share of large firms (Figure 10, Panel A). This share has even been dwindling over the past few years. Recent firm-level analysis highlights the positive relationship between the size of a Portuguese firm and their probability to export (Correia and Gouveia, 2016; Amador, Ringstad and Cabral, 2018).

Against this background, identifying specific areas where public policy can both support market entry and firm growth is integral for achieving further improvements in Portugal's export performance. Lowering administrative burdens on firms, ensuring that the design of 
existing public policies do not impede firm growth and enabling access to finance are all apposite. The potential for public policy reforms to support firm growth may be especially large in Portugal, given that bureaucracy remains often cited by businesses as an impediment to firm expansion (Figure 10, Panel B).

Figure 10. There is scope for government reforms to support firm growth

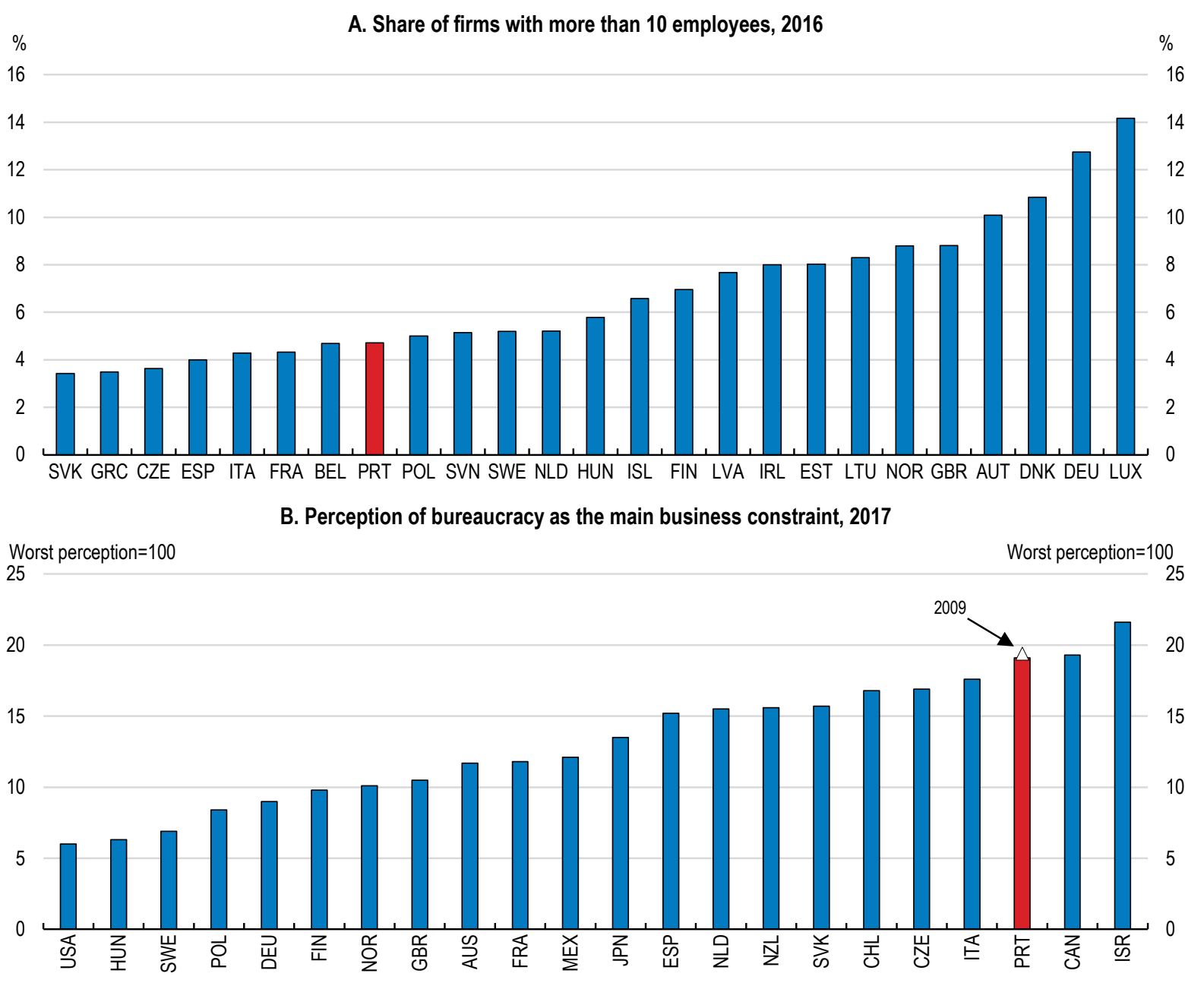

Source: Eurostat, World Economic Forum.

\section{Reducing administrative burdens}

Administrative burdens raise compliance costs for firms that hamper their entry into new markets, their expansion and cost competitiveness. Particularly burdensome procedures may also deter new foreign direct investment. Firm level empirical analysis by the OECD has highlighted the negative impact of higher administrative burdens on productivity in the Portuguese business sector (Arnold and Barbosa, 2015).

The administrative load on Portuguese businesses has gradually reduced over time. Between 2003 and 2013, the OECD indicator of administrative burdens on start-ups declined by around 9\% (Figure 11). Overall, the reduction in policy barriers to entrepreneurship over this period are estimated to have increased Portugal's GDP per capita by $7 \%$ over the long-run (Égert and Gal, 2018). 
Figure 11. Administrative burden on business has declined over recent years

OECD Product Market Regulation Administrative Burdens on Start-ups Sub-indicator

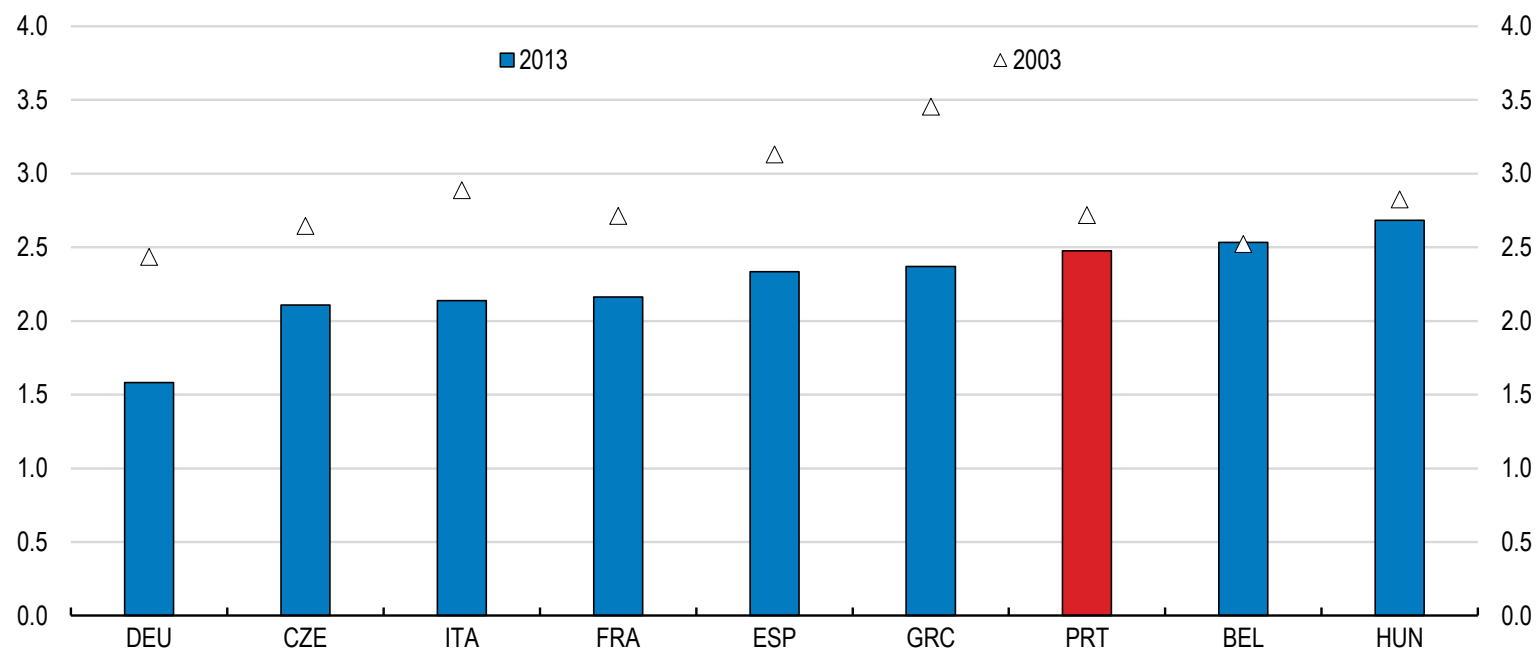

Source: OECD Product Market Regulation Indicators.

Specific reforms included the active rationalisation of licensing procedures: licensing surcharges levied by municipalities were eliminated, environmental licenses consolidated and the Zero Authorisation initiative implemented. The latter substituted various formal authorisation procedures with businesses making a declaration via the Point of Single Contact e-government portal. Legislation on industrial licensing (SIR) was also adjusted in 2015 , following a significant reform a few years earlier. These measures have been associated with a subsequent reduction in the average time for decisions on new licenses.

The ongoing implementation of the Simplex + programme has also been aimed at reducing the administrative burden on firms and households (Box 3). An evaluation of selected measures in the Simplex+2016 programme found that they substantially reduced the time required by businesses to comply with public administration (European Commission, 2018). Further analysis of the economic impact of specific Simplex+ measures is advisable, as such information will provide useful guidance in identifying additional reform priorities. 


\section{Box 3. Portugal's Simplex+ Programme}

Launched in 2016, Simplex+ was a national simplification programme launched to create new online public services, optimise existing ones and de-bureaucratise the relationship between public institutions and civil society. Similar to an earlier programme that ran between 2006-2011 ("Simplex"), the initiative was designed based on a bottom-up diagnosis of the services and laws requiring simplification.

Compared to the earlier version of the programme, Simplex + was more cooperative in its process, placing the needs of users of public services as the primary criterion for identifying priority areas for action. In this spirit, the diagnosis was performed through broad consultation across citizens, corporates and public officials, facilitated through open events in the 20 national districts, a website and Facebook page and additional meetings with representatives from the main economic sectors and public service. The consultation also involved a competition to reward innovative ideas for products that could be integrated in the public administration ("Startup Simplex").

This process enabled the design of a simplification programme consisting of 255 measures that were implemented by the end of 2017. The implementation of this programme has been subject to monitoring and evaluation by external and independent entities, namely with regards to its impact on businesses. A recent study that evaluated 13 Simplex+ measures estimated that 624 million euros per year in administrative costs were saved by companies as a result of their implementation (Gabinete da Secretária de Estado Adjunta e da Modernização Administrativa, 2017).

Source: OECD Observatory of Public Sector Innovation

While commendable, the reduction in administrative burdens in Portugal has not been exceptional in the context of other comparable countries: for example, Spain, Italy and Germany had a much larger fall (Figure 11). Despite the simplification of bureaucratic procedures, their operation can also be negatively impacted by administrative inefficiencies. For instance, despite single windows to receive applications, behind-thescenes consultations between different authorities can be slow moving in Portugal (OECD, 2017a). The administration of some policies, such as those governing land use, have also been conditioned by strong discretionary powers of municipal governments which has hindered administrative efficiency in some locations (OECD, 2017a).

Tax administration is an area that remains particularly cumbersome for businesses. While there are various methods for measuring tax compliance costs, the widely used World Bank Doing Business Indicators suggest that preparing and paying taxes consumes an inordinate amount of hours in Portugal compared with other OECD countries (Figure 12). Around two thirds of businesses surveyed in 2017 regarded the Portuguese tax system as "complex and ineffective", an increase of around 10 percentage points from two years earlier (Deloitte, 2017). This is despite recent initiatives including the increased digitalisation of tax procedures and automatic filing of information already in the databases of public entities. 
Figure 12. Tax administration takes significant time for businesses

Time to prepare and pay taxes, 2018

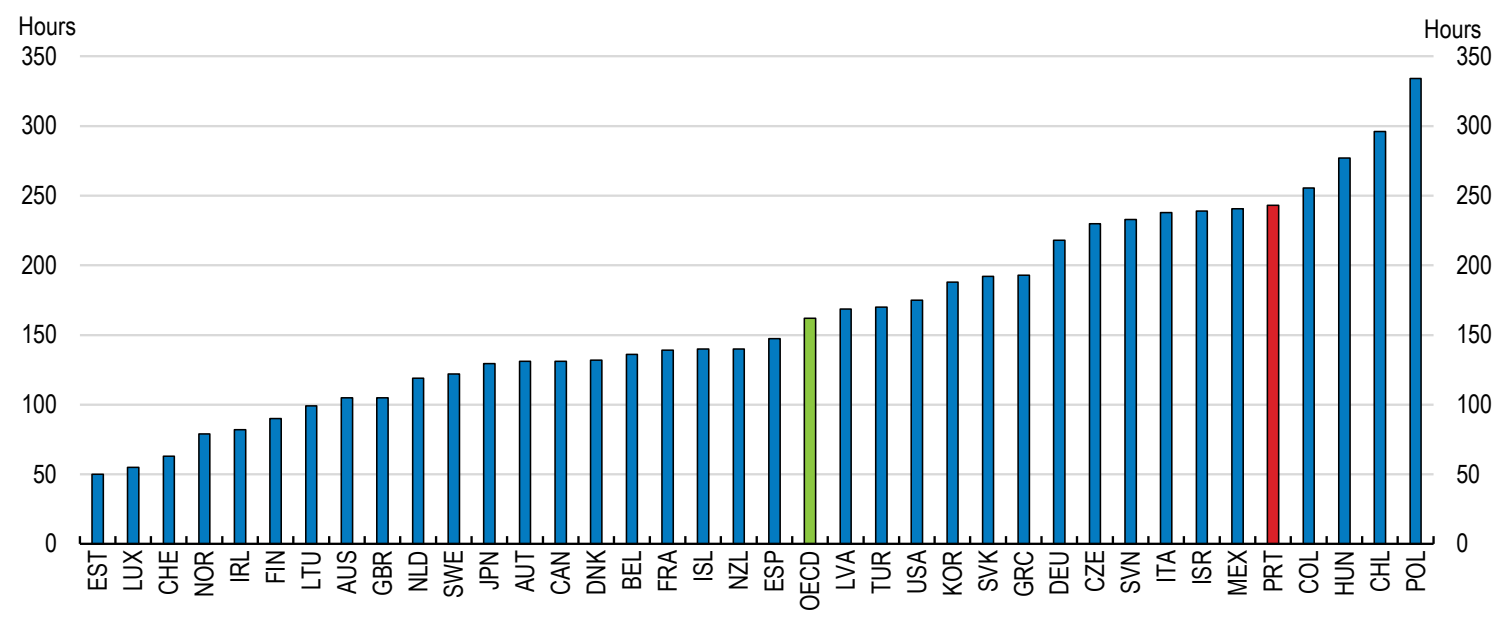

Source: World Bank Doing Business Indicators.

The vast majority of surveyed Portuguese tax accountants (Técnicos Oficiais de Contas) also consider the tax system to have a high level of complexity (Borrego et al., 2015). Both tax officials and businesses highlight frequent changes in tax laws as the most significant contributor to complexity in the tax system. However, other factors include the extensive use of special provisions and ambiguity in the tax law language. The former may be motivated by equity goals, but can generate deadweight losses by encouraging rent-seeking or tax-planning behaviour. In addition, the overuse of special provisions raise tax compliance costs for businesses. OECD empirical work has highlighted the negative effect of such costs on the productivity of Portuguese enterprises, and hence their export prospects (Arnold and Barbosa, 2015).

\section{Reforming other policy settings that discourage or hamper firm growth}

In addition to administrative costs for firms, specific features of public policies can negatively impact the growth of firms and, hence, their likelihood of becoming exporters. This may be through regulations exhibiting a bias towards small firms. Further, settings that do not sufficiently promote competition in important industries that produce intermediate inputs, such as professional services, can raise costs for exporters downstream.

\section{Corporate taxation}

Differential corporate income tax rates may impede the expansion of Portuguese firms. The statutory tax rate was reduced to $25 \%$ in 2015 , but there are various differential rates that result in lower effective statutory rates for smaller firms but higher effective statutory rates for more profitable firms. Rate reductions for smaller firms are poorly targeted, given that such enterprises per se do not create more jobs and innovations nor do they face insurmountable financing constraints (Bergner et al., 2017). The rate of the corporate tax surcharge increases as taxable profits rise. The surcharge for companies with taxable profit exceeding EUR 35 million was raised from 7\% to 9\% in 2018, implying a top statutory corporate income tax rate of $30 \%$. There is also a reduced rate of tax paid by small to medium enterprises (defined as those with turnover below $€ 50$ million, which employ less than 250 people and an annual total balance sheet below $€ 43$ million) on the first EUR 
15,000 of taxable profits, though this relief is very modest compared with similar provisions in other European economies (Bergner et al., 2017).

A reduced corporate tax rate for smaller firms may be adopted on the basis that larger firms are more effective at structuring operations to minimise their corporate tax bill. However, past OECD work suggests that the investment decisions of small firms tend to be less sensitive to corporate taxes than those of larger firms (OECD, 2010). Furthermore, such provisions may incentivise them to cap their growth and misreport taxable income or business size to the authorities (Bergner et al., 2017). The costs and benefits of having a progressive corporate income tax rate system with a preferential tax rate for small and medium firms and rates that are increasing with business profitability should be reviewed.

At the same time, the potential effects of a planned introduction of preferential tax rates for companies in the interior of the country should be rigorously evaluated. Under the plan, both existing businesses as well as those that are newly established in interior regions will receive a $20 \%$ corporate tax bonus. This may encourage profit-shifting within the country. Furthermore, it is likely to induce a reallocation of resources away from Portugal's substantially more productive regions, such as the Lisbon metropolitan area, weighing on aggregate productivity and the growth of some high-potential exporting firms. There is currently a suit of government policies aimed at developing interior regions in Portugal, including through direct support to enterprises and the delocalisation of public services. To further promote business activity in these areas, it would be advisable for the government to allocate more public funds to investing in the construction of complementary public assets rather than introducing distortions into the corporate tax system.

The growth of new exporters can also be impeded by the design of Portugal's public support for business research and development (R\&D). In Portugal, the majority of such support comes in the form of R\&D tax credits. Such policy instruments favour less dynamic incumbents at the expense of young businesses because their implicit subsidy rate increases with firm profitability and young firms are often in a loss-making position in the early years of an R\&D project (OECD, 2015).

Some features of Portugal's $R \& D$ tax incentives aim to reduce the discrimination against small loss-making firms. In particular, unused tax credits can be carried-forward and used against taxable income over the next 8 years. Even so, a claim will have a lower present value to loss-making businesses that receive it at some point in the future than to profitable firms that receive it immediately (owing to time discounting; Figure 13). Some firms may also not have sufficient taxable income over the allowed eight years to use the tax credits or the upfront funds to start an R\&D project without the government support being made available immediately. The Portuguese authorities could consider reforming the R\&D tax incentive to allow unused tax credits to be indefinitely carried forward or for cash refunds of R\&D tax credits. Such provisions are commonly used across the OECD, with countries including Belgium, Italy and the United Kingdom having indefinite carry forward of R\&D tax credits and others including Australia, Canada and France offering cash refunds of R\&D tax credits (OECD, 2018b) However, the benefits of such a reform should be weighed up against the associated fiscal cost. If adopted, it should be coupled with safeguards to prevent abuse and measures that ensure regular ex-post evaluation of the policy. 
Figure 13. Portuguese R\&D tax incentives are more beneficial for profitable firms

Tax subsidy rates on R\&D expenditures for small and medium enterprises, 2017

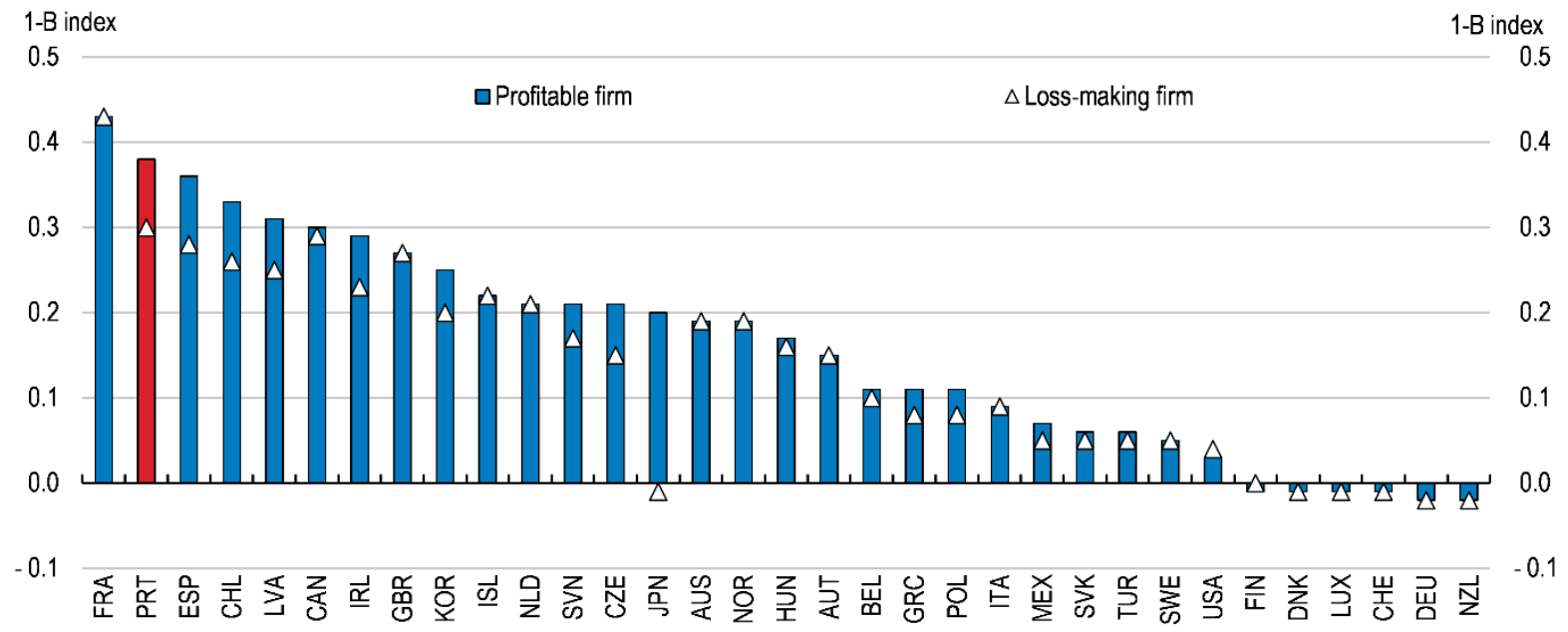

Note: (1-B-index) increases in the generosity of R\&D tax incentives. Specifically, the B-index represents the pre-tax income needed for a representative corporation to break even on a marginal monetary unit of R\&D outlay taking account of both R\&D tax incentives and the corporate income tax rate.

Source: OECD STI Scoreboard 2017 (database).

\section{Regulations in services sectors}

The price and quality of services inputs can have a strong influence on the competitiveness of Portuguese exporters, since such inputs are often sourced domestically. The fact that services account for $36 \%$ of Portugal's gross exports, but $58 \%$ in value added terms, highlights the significant reliance of the overall export sector on the services industries. In recent years, the growth in services prices has been stronger than in other parts of the economy (Figure 14). This has coincided with especially weak productivity growth in the non-tradable services sector due to weak efficiency in resource allocation (Bank of Portugal, 2018a). Services sectors have traditionally been characterised by low levels of competition in Portugal (Amador and Soares, 2012; Amador and Soares, 2014), partly owing to the stance of regulatory policies. Reforms over the past few years have improved policy settings, but there is scope for further strengthening competition in some areas. 
Figure 14. Services prices have risen relatively rapidly

Index of consumer prices, $2008=100$

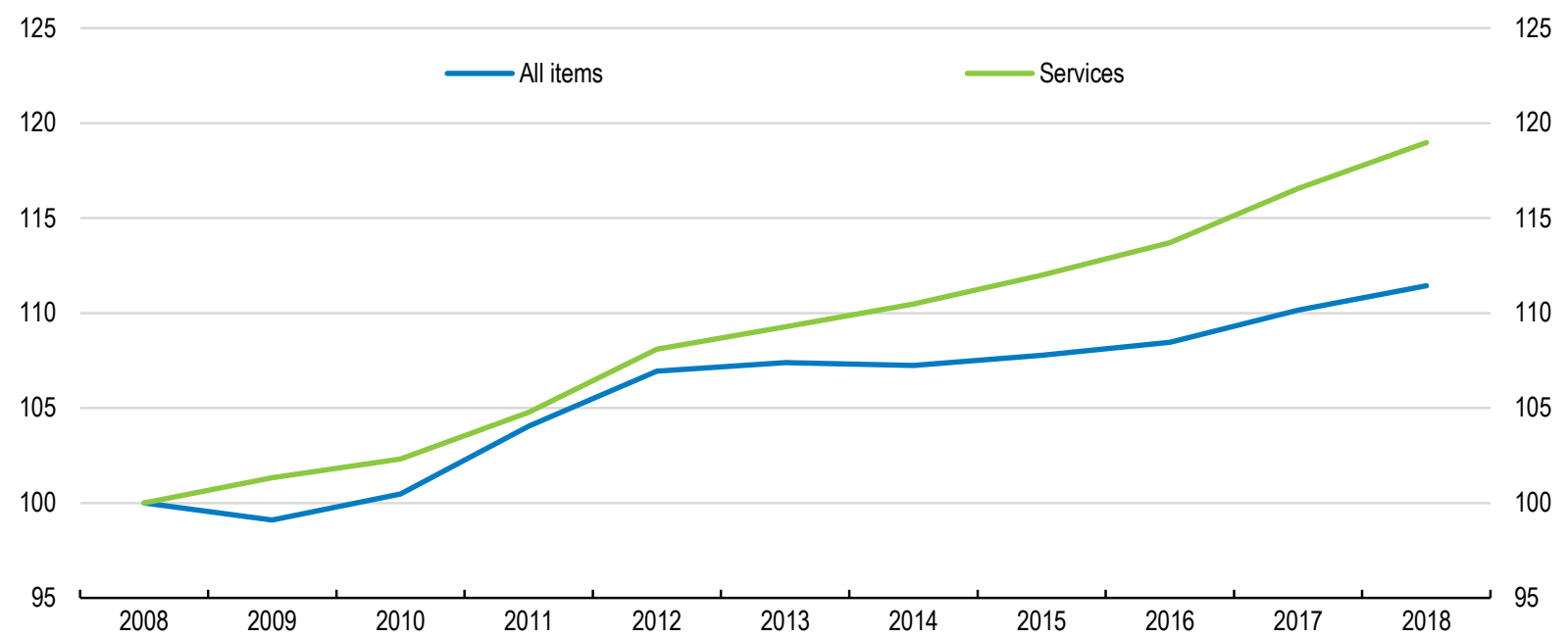

Source: Eurostat.

Regulatory settings in some of Portugal's professional services, such as accountants, lawyers, architects and engineers, are more restrictive than in most other OECD economies (Égert and Wanner, 2016). The OECD Services Trade Restrictiveness Indicator (STRI) also highlights barriers to competition through international trade in these services (Figure 15). Some of these relate to nationality requirements for owning and practicing in these professions. A propensity for professional bodies to erect barriers to competition in selfregulated service professions is often the foundation of such restrictions.

Figure 15. Restrictions on trade in some professional services reduce competition

Services Trade Restrictiveness Index, 2018

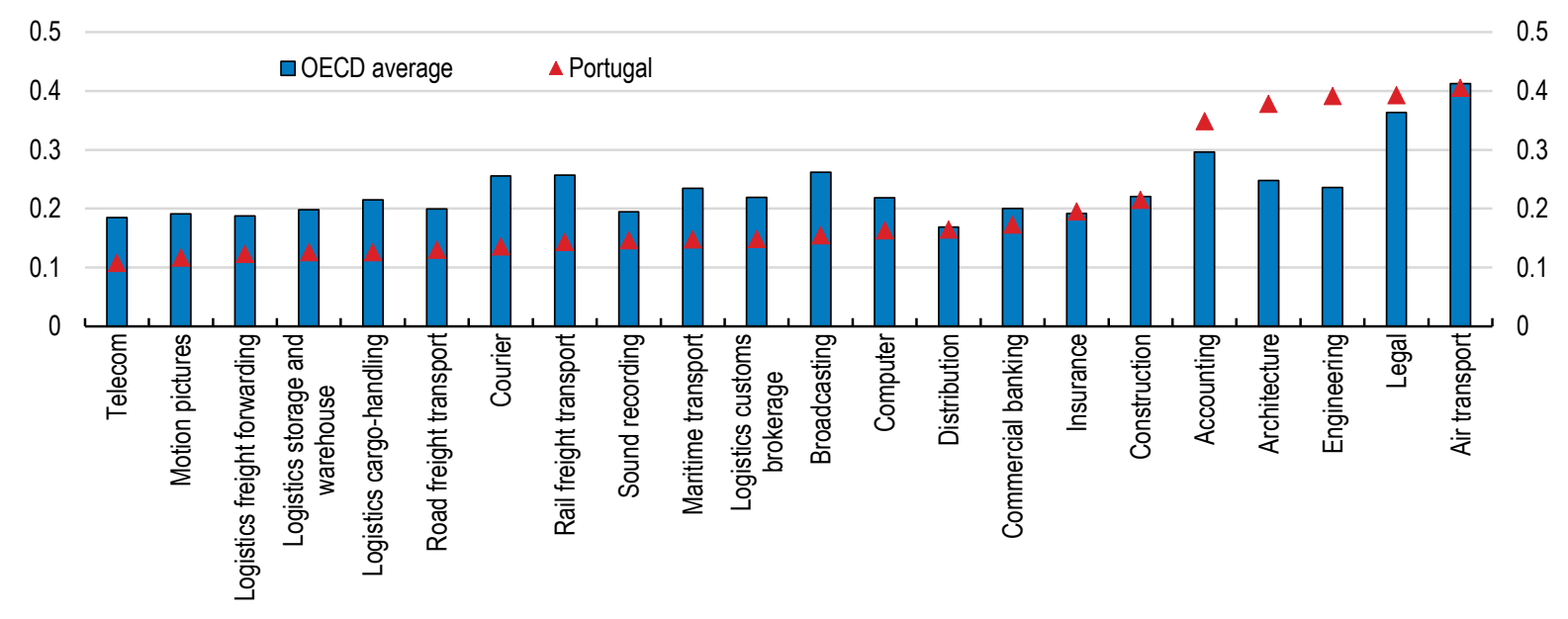

Source: OECD (2018), Services Trade Restrictiveness Index (database).

In 2018, the OECD collaborated with the Portuguese Competition Authority to complete an assessment of competition in self-regulated professional services. This highlighted some features of the regulatory framework that stifle competition and contribute to rents accruing to incumbents. Protective powers of the regulatory professional bodies and the use of 
exclusive rights that reserve certain tasks for members of the profession were two of the main areas singled out as ripe for reform.

The regulatory and representative roles of professional associations should be separated to better promote competition. The Portuguese Constitution currently allows professional associations to both represent its members and regulate access to, and the exercise, of the profession. Under such an arrangement, associations have an incentive to adopt anticompetitive measures that protect the professionals they represent. Such practices have occurred across a number of professions in Portugal over recent years (OECD, 2018c). Instead, separate supervisory bodies should be established that undertake all regulatory functions independent of the representative entity. This may be through the establishment of autonomous supervisory bodies (grouped by sector or trade) or through the creation of independent "boards" within the professional associations. In the latter case, such boards should include experienced individuals from other regulators or organisations, representatives from consumer organisations and academia (OECD, 2018c). Nevertheless, such a setup would need to be coupled by strict "Chinese walls" to safeguard the independence of the entity.

Tight regulations related to academic qualifications for practicing a professional service also restrict competition. Individuals with a different education than a university degree usually have difficulty gaining registration in a professional service in Portugal. A particularly relevant self-regulated profession for exporting firms is customs brokers. At present, to register with the professional association of customs brokers, an applicant must hold a university degree in economics, management or business administration, law, international relations, international trade or logistics and customs. The requirement for customs brokers to hold a university degree was introduced in 2015, but it excludes other individuals who have obtained the necessary skills through their professional activities or an educational path outside university. By limiting the supply of such professionals, the current regulations can increase costs for exporters and add to the perceived inefficiencies in customs procedures that already exist in Portugal (Figure 16). They are also likely to reduce diversity in the profession and the services offered, with potential negative implications for innovation. 
Figure 16. Inefficient customs processes may be exacerbated by barriers to the customs broker profession

Efficiency of customs clearance process, 2018

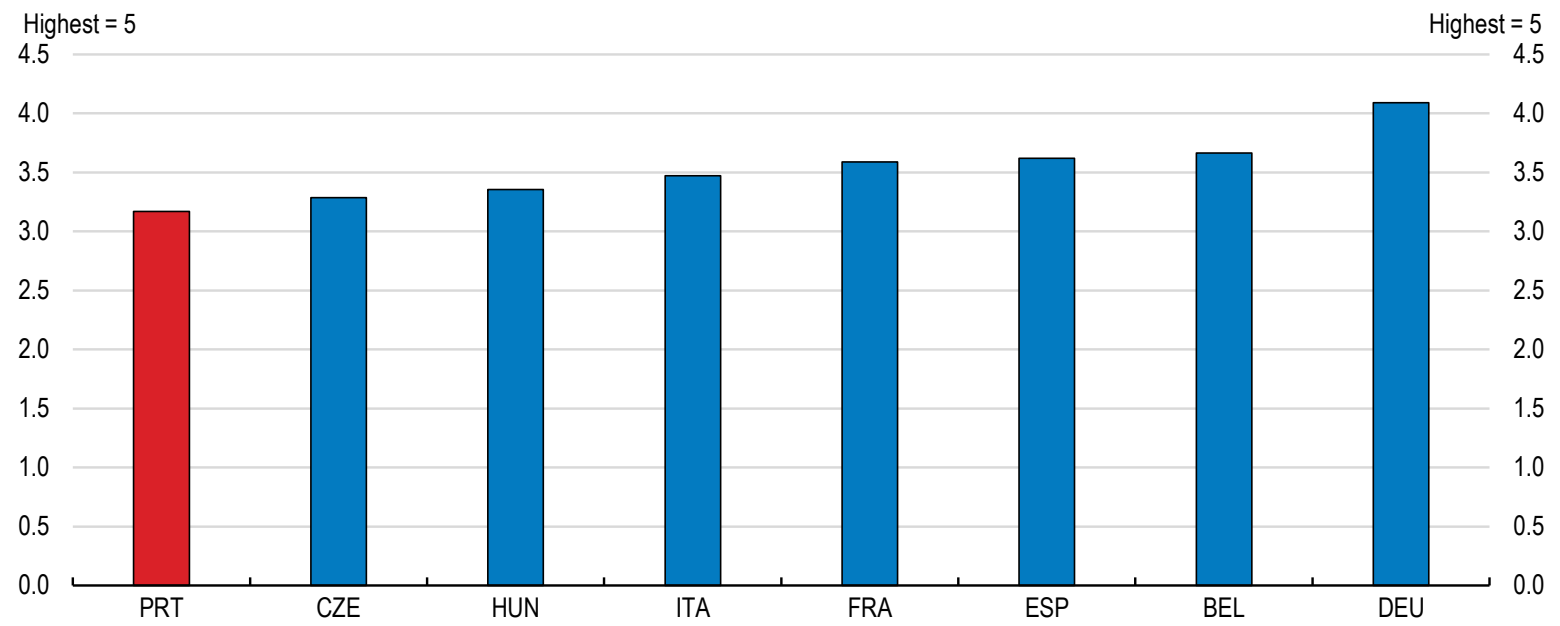

Source: World Bank and Turku School of Economics, Logistics Performance Index Survey.

Several professional services are also afforded exclusive rights to perform certain activities in Portugal. Such provisions have traditionally been designed to ensure a standard of quality for consumers, protecting them from information asymmetries related to service quality. Nevertheless, they also lower competitive pressures on incumbents and may be increasingly unnecessary with the advances in information diffusion made possible by new technologies. For instance, customs brokers are given exclusive rights over some activities, including representing firms to the relevant authorities in carrying out customs formalities and drafting requests for businesses to obtain simplified regimes. As recommended in the OECD Competition Assessment of Self-regulated Professions in Portugal, such activities for customs brokers should be abolished.

In July 2018, the Portuguese Competition Authority outlined an action plan to implement OECD recommendations related to professional services. Given the importance of such services to the ongoing expansion of the export sector, the full implementation of these recommendations should be a priority for policymakers across government.

\section{Improving access to finance}

Across countries, difficulties gaining access to finance can be an obstacle for the growth of exporters, especially for young firms in a bank-based financial system (such as Portugal) that have a limited track record and minimal collateral. For such firms, the high fixed costs of establishing a distribution network, international marketing and potentially adjusting products for overseas regulatory standards, often requires external finance.

The financial crisis exacerbated financing constraints (Lee, Sameen and Cowling, 2015), particularly in countries such as Portugal with banking systems that were hard hit. In a survey by the Bank of Portugal, Portuguese firms reported increased difficulties in accessing credit as one of the most severe aspects of the economic shock in the 2010-13 period. Through that time, around $30 \%$ of firms reported a moderate or strong increase in credit constraints (Martins, 2016). 
In the past few years, there has been a notable improvement in access to finance for Portuguese enterprises. Between April 2014 and March 2018, the proportion of SMEs citing access to finance as their most important problem halved to be less than $10 \%$ (European Central Bank, 2018). In accordance, borrowing costs declined (Figure 17) along with the spread between the interest rate charged to smaller and larger firms (OECD, 2018d). While there has been little discernible increase in the stock of credit to exporting firms, venture capital financing has been steadily rising since 2011, suggesting greater ability for young entrepreneurial exporters to gain finance.

Figure 17. Borrowing costs for Portuguese firms have declined rapidly

Interest rates on loans to corporations, percentage

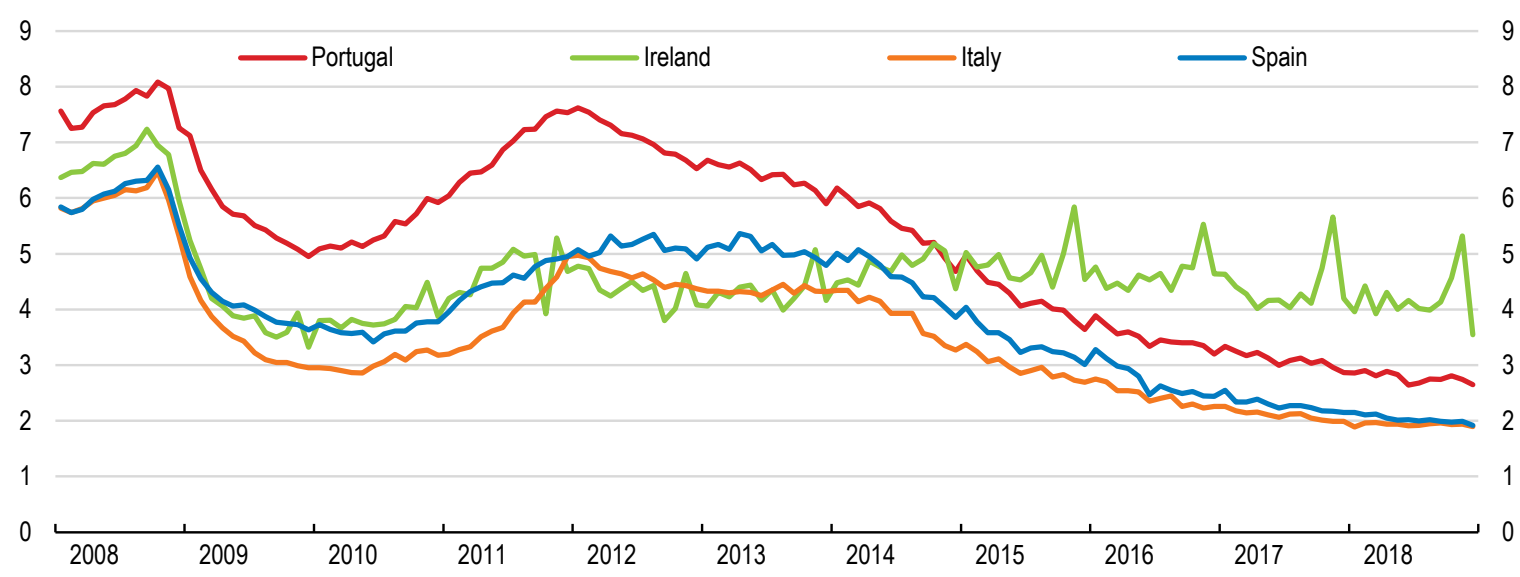

Note: All corporations are non-financial (NFC) and loans are from monetary and financial institutions.

Source: European Central Bank.

The improvement in borrowing conditions for businesses has reflected the cyclical recovery, the improved health of the banking sector and focused government policies. The latter have recently been under the umbrella of the Capitalizar programme, which was launched in 2016 with the specific aims of improving financing conditions for SMEs and the capitalisation of companies more broadly. Measures include the introduction of new credit lines focused on SMEs that amount to 15.8 billion euro (around $20 \%$ of the stock of non-financial corporation credit). Loans under these credit lines have long-term maturities (up to seven years), partially subsidised interest rates and public guarantees that cover between $50-75 \%$ of the loan. There have also been specific measures for financing entrepreneurs, including public co-investment in venture capital and business angel financing. Public support for entrepreneurs through partnering with the private sector in this way is prudent as it is more likely to succeed in fostering a sustainable early-stage capital sector as well as help avoid the common pitfalls associated with government "picking winners".

To facilitate the expansion of the export sector, measures that further improve firm's access to finance at the same time as ensuring ongoing improvements in financial stability need to be identified. For instance, medium-sized firms should be further encouraged to source finance from equity markets. Recent measures that reduced the debt bias in the corporate tax system and allowed the creation of a new type of listed company that holds shares in unlisted Portuguese firms are important in this regard. Direct stock listings of SMEs in Portugal are rare compared with other OECD countries, such as France or the Netherlands. Some public support should be allocated to improving the services that help such 
companies become listed and consideration should be given to introducing a lighter regulatory regime for such firms once they list.

New sources of financing, such as the emergence of providers utilising innovative financial technology ("FinTech") should also be encouraged. Such platforms may particularly benefit young entrepreneurial firms that have non-standard business models but a high degree of digital awareness. FinTech looms as an important vehicle for business-tobusiness trade financing. Given empirical work has highlighted the role of trade finance in substituting for bank finance in the event of financial shocks (McGuinness and Hogan, 2016), the development of a FinTech sector can help improve the resilience of Portuguese exporters. It may also reduce business costs through injecting greater competition into Portugal's financial services market. That said, new financing vehicles should be carefully regulated to ensure that they do not contribute to the build-up of systemic financial risks.

\section{Ensuring domestic infrastructure promotes better export performance}

The ability of Portuguese firms to become more export-oriented will rely on efficient domestic infrastructure that can cope with increased production volumes. Both the quality and cost of physical infrastructure such as ports, rail, roads and airports impact the ability of businesses to take advantage of the global fragmentation of production networks. Such infrastructure, along with other forms such as tourist accommodation, can also support the sustainability of Portugal's tourism boom. However, perception-based indicators suggest that the quality of ground, port and air infrastructure can be improved (Figure 18). While Portugal faces fiscal constraints which limit the potential for a significant increase in public capital investment, reforms to regulatory settings can have significant benefits to the functioning of domestic infrastructure with no financial cost to the state.

Figure 18. Domestic infrastructure can be improved

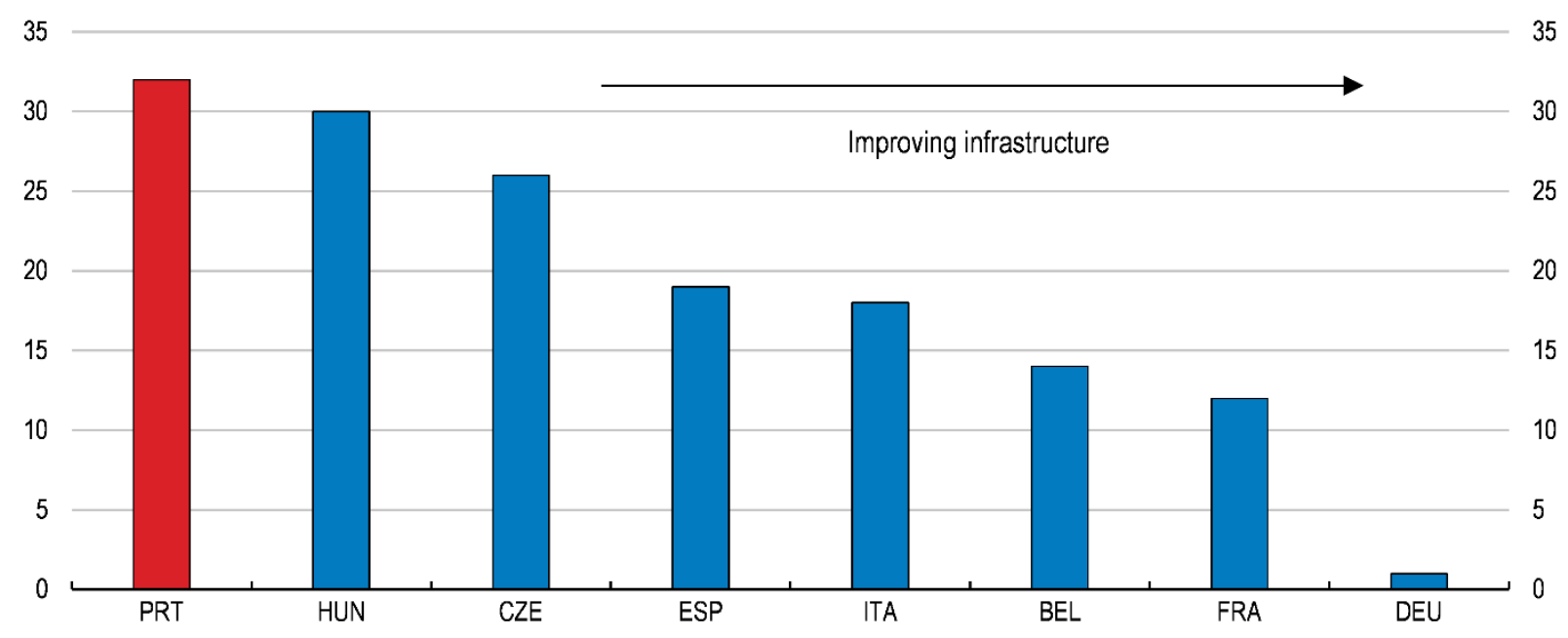

Note: The figure presents a ranking for logistics infrastructure across 160 countries in 2018, based on a survey of global freight forwarders and express carriers.

Source: World Bank Logistics Performance Indicator.

\section{Transport}

Maritime transport accounts for over one-third of Portuguese freight movement (Statistics Portugal, 2017). Portugal is strategically positioned at the intersection of major shipping routes between Europe and America and Europe and Asia, an appealing location for foreign 
investment in the downstream activities of global value chains. Nevertheless, the ability to attract such investment depends on the adequacy of port infrastructure and ancillary services. For domestic firms, such infrastructure is similarly important for accessing foreign markets.

Portuguese ports follow the "landlord port" model whereby the port authority manages and invests in the main port infrastructure, while private operators are able to operate port activities and invest in superstructures such as equipment and terminal buildings. This is a common port model employed across OECD countries (OECD, 2018e). However, various aspects of the regulatory framework governing the Portuguese port system stifle competition and the efficiency of their operation. There appears to be substantial scope for improvements in Portuguese port efficiency. For example, cost-efficiency analysis suggests that the costs of port piloting services could be reduced by around $50 \%$ (OECD, 2018e). While the ongoing renegotiation of port concessions is being used to introduce performance-oriented objectives, with the intention of lowering user charges, progress is slow.

Some regulatory settings limit the scale of private operators that can undertake port activities, reducing competitive pressures on incumbent operators. For example, port authorities tend to directly provide ancillary services, leaving little room for participation of private operators, and affording the authority significant market power. In some port services such as piloting and cargo-handling, regulations restrict the ability for port authorities to license multiple private operators, instead favouring to grant a concession of exclusive rights to a single entity. In cases where multiple port operators could co-exist in the same port, such bias in the regulations will eliminate the potential for ongoing competition in these services markets, reducing efficiency and raising costs for exporters.

Barriers to entry also exist in the form of onerous financial requirements for an operator to provide services. These requirements are often based on fixed minimum thresholds, not proportional to the size of the operator, which discriminates against services being provided by smaller firms (OECD, 2018e). In the case of cargo-handling, licensed operators must demonstrate their financial ability to carry out services by: i) paying a financial guarantee to port authorities that is fixed across operators, ii) demonstrating a minimum amount of share capital invested in the company (the threshold varies by port, but for Lisbon it is equivalent to EUR 1000 000) and iii) possessing subscription to an insurance policy covering a minimum capital of EUR 100 000. However, the rationale for having three separate requirements is not clear, especially when such provisions reduce the number of private providers that can operate in the market. Instead, consideration should be given to amending the regulations so that only a subscription to an insurance policy, with the minimum covered capital being determined by an assessment of the operational risks of the particular licensed operator, be required.

Regulations also exist that specify minimum levels of equipment and the forms of work contract that can be used by private operators. In the case of cargo-handling operations, national legislation requires operators to employ an exclusive group of workers and to own the equipment, machinery and vehicles. Such requirements restrict the ability of operators to organise themselves in the most efficient way, as they can exclude other contractual arrangements such as leasing equipment or the use of temporary staff. The current regulations seek to ensure that private operators have the capacity to provide the necessary services. However, a better way to ensure this, while not restricting the allocation of resources or market entry of operators, would be to establish minimum levels of public service or to enable the use of pools of equipment. 
The characteristics of port concession contracts may also hamper competitive pressures and the efficiency of Portugal's freight transport. The concession of exclusive rights to a single private operator is useful in instances where ongoing private competition in the market may not be viable or substantial investment is required by the operator. In Portugal, concessions are particularly common for cargo handling services. The contracts can be structured to introduce competition into the market by being awarded based on a competitive bidding process. The framework for granting concessions is important as one which is poorly designed can grant monopoly rights to inefficient operators that may charge high tariffs to exporters for an extended period of time.

The duration of port concession contracts in Portugal are frequently excessive, reducing the potential for market entrants that can positively influence innovation and competitive tariff pricing. The length of the contracts are at the discretion of the port authority, but subject to certain maximum ceilings imposed by law. In setting contracts, the port authorities are compelled to follow the new Public Contracts Code, which came into effect in January 2018, that specifies that the term of the contract be fixed according to the period of time necessary for amortization and reasonable remuneration. It should be ensured that the new code is followed closely. Analysis contained in the OECD Competition Assessment Review of Inland and Maritime Transports and Ports, highlights a very weak correlation between the investment spending of private operators and the length of concession contracts previously awarded in Portuguese ports (OECD, 2018e). Furthermore, some terminal concessions have been renewed at the end of a contract for an extended period without a new competitive awarding procedure being undertaken. In granting concessions, the contract should explicitly determine a minimum level of investment to be incurred by the operator and it should not be renewed without the opening of a new public tender.

The structure of concession revenues (i.e. the charges levied by port authorities on private operators) may also negatively impact upon the efficiency of the port system. Unlike the majority of European ports, such levies comprise both a fixed charge (which is most common in other jurisdictions) and a variable component in Portugal. The latter may be justified if port authorities incur costs that vary with production, but such variable concession charges in Portugal largely exceed those costs (OECD, 2018e). The problem with having significant variable charges for private operators is that it can reduce the incentive for such firms to increase the volume of cargo or passengers handled. Instead, fixed charges should be the main mode of levying fees, with variable charges only applied in instances where the port authority has incurred variable costs.

The competitiveness of Portuguese ports is also undermined by the fact the process for awarding concessions gives insufficient consideration to the bidder who will charge the lowest price to port users. Instead, concessions are usually awarded to the bidder willing to pay the highest price to the port authority. This is consistent with the fact that many Portuguese port authorities primarily seek to maximise profits, despite being state-owned companies (OECD, 2018e). Strong financial performance of the port authorities is commendable, but not when it comes at the cost of inefficiencies in the port sector that reduce the competitiveness of the economy.

Improvements to the port system can achieve their maximum potential benefit for the export sector if combined with better connections to international rail freight services. Rail density is low in Portugal and rail links between the Portuguese and Spanish freight market have been too limited. In 2018, a tender for the 94km Évora-Elvas-Caia rail line was launched. This project will connect key Portuguese ports including Setubel and Sines with transport hubs in Spain. However, as detailed by the European Commission, a joint strategy 
by Portugal and Spain including the deployment of rail interoperability in the Iberian Peninsula and its connection with the French rail network is still missing (European Commission, 2018). Differences in the rail gauge, the maximum train length and signalling systems compared with other key European markets, such as France and Germany, impedes trade connections. These are challenges that are well recognised by the Portuguese authorities and overcoming them should continue to be a priority.

Road transport accounts for the majority of freight and passenger movement in Portugal. Portugal's limited rail network makes it especially dependent on the network of roads to move freight and people within the country. While the need for reforms are not as pronounced as in Portugal's port sector, the competiveness of the economy can be enhanced by policy changes that reduce barriers to new freight and passenger transportation companies entering the market.

While the road sector is mainly governed by European Union legislation, some regulations are stricter in Portugal than the EU guidance. For example, those operating "light trucks" in Portugal (those between 2.5 tonnes and 3.5 tonnes) are covered by the mandatory licensing regime for freight operators that requires the fulfilment of various licensing requirements $(\mathrm{OECD}, 2018 \mathrm{e})$. However, EU regulations only require the use of an EU Community licence for vehicles above 3.5 tonnes.

Portuguese airports have seen a steep increase in demand with the boom in tourist inflows. Lisbon airport is operating close to full capacity and there are plans for a second international airport in Montijo, 20 miles from Lisbon by road. To be effective, the new airport will need to be complemented by transport links that effectively connect it with the broader city. While Portuguese airports are operated under a 50 year concession agreement with a private company, the feasibility of expanding capacity of the Lisbon airport or the ability for the government to induce efficiency improvements in that facility should also be thoroughly investigated.

More generally, the government should ensure that the governance around public investment decisions ensures that projects with the highest long-term economic and social returns are prioritised. Public investment decisions should be made in the context of a longterm national strategic vision that addresses infrastructure service needs, how they should be met and the responsible entities (OECD, 2017b).

\section{Tourist accommodation}

The stock of housing infrastructure has come under considerable pressure in recent years. While the tourism boom and government policies tying non-resident visas to dwelling investment have boosted demand (especially in Lisbon, Porto and the Algarve), growth in the stock of housing supply has not kept pace. The latter has largely been a legacy of the slump in construction activity through the financial crisis: between 2007 and 2014, annual housing investment fell by over $50 \%$.

In recent years, there has been a steady increase in the supply of tourist accommodation. The number of beds in tourist accommodation rose by 23\% between 2013 and 2017, with one-third of the growth attributable to a rise in the use of rooms in local housing by tourists (Figure 19, Panel A). In Lisbon, listings on Airbnb (an online marketplace that allows people to rent-out their properties or spare rooms to guests) more than doubled between 2015 and 2017. Nevertheless, tourist demand has outpaced supply over the past few years (Figure 19, Panel B). This has resulted in strong growth in prices for tourist accommodation (Figure 19, Panel C) and contributed to the upward pressure on dwelling rents and prices 
more generally (Bank of Portugal, 2018b). These trends risk reducing the competitiveness of Portugal's tourism sector and prompting policy interventions that limit its expansion. Moreover, higher housing costs for professionals may dissuade foreign investment in the business sector.

Figure 19. Rising tourist demand has pushed-up accommodation prices

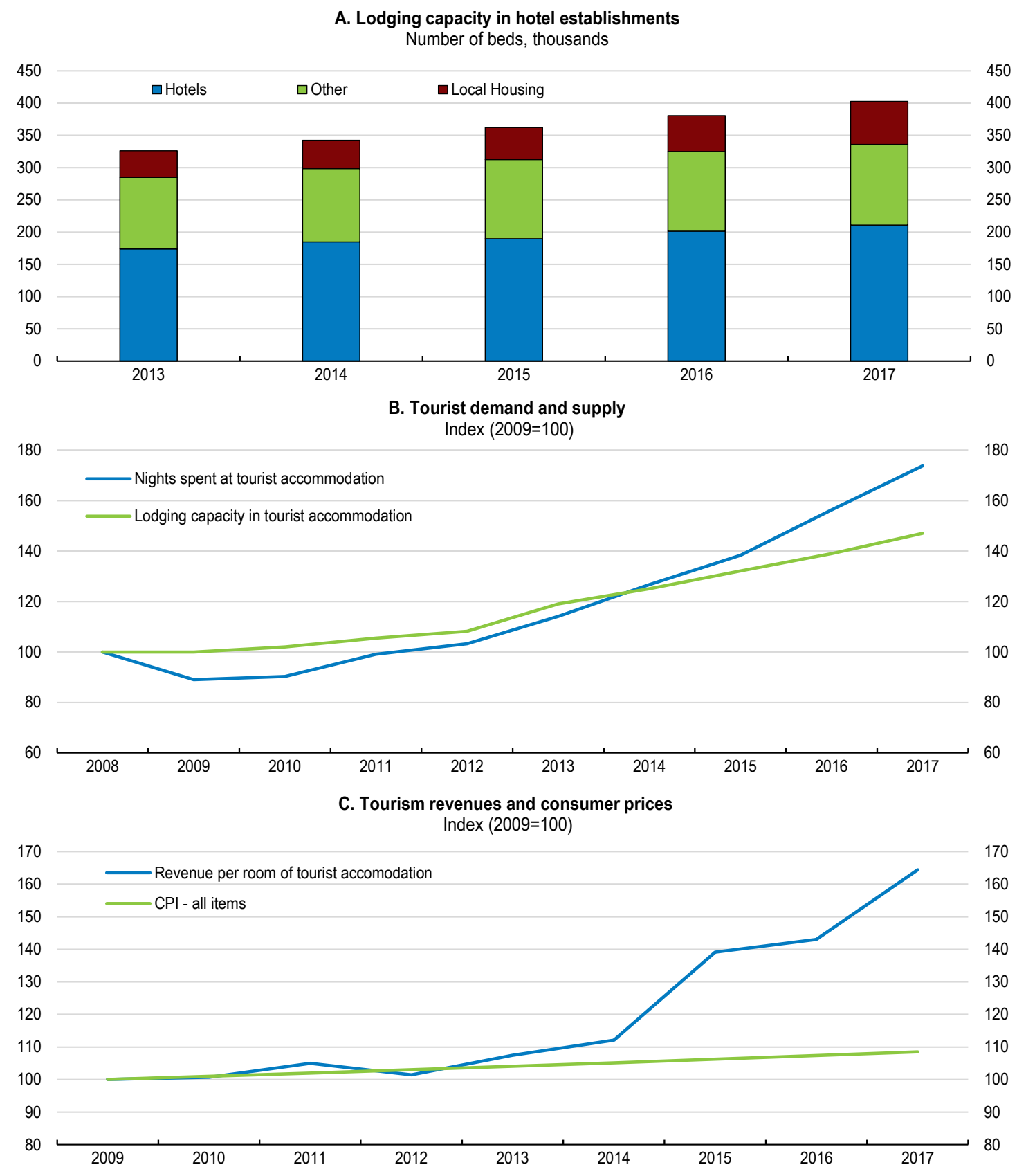

Source: Pordata, Eurostat.

In response to the rise in local housing for tourist accommodation, the authorities have been active in updating the regulatory framework. All hosts must now register shared short-term accommodation with local authorities, comply with basic standards including fire safety 
and possess multi-risk insurance that covers damage in common areas of apartment buildings. These provisions protect consumers and ensure that hosts comply with their tax obligations. Nevertheless, some of the new regulations may reduce or limit the availability of local housing for tourist purposes.

As of October 2018, municipal councils have a more powerful role in influencing the supply of local housing. Along with taking on new responsibilities for fining and forcing the closure of existing units, councils are now able to create "containment areas" where the number of tourist establishments can be restricted. In addition, the new regulations stipulate that owners of apartments for tourist accommodation may be charged an additional $30 \%$ annual contribution to the association governing the building. The council will now also force the closure of an apartment used for local accommodation in cases where over half the residents in an apartment building are in opposition.

There is a tension between facilitating the expansion of well-located tourist accommodation and ensuring that culturally-rich areas are not stripped of their authenticity. In trying to navigate these dual objectives, the authorities should carefully evaluate the impact of the new regulations on the stock of tourist lodging. At the same time, complementary reforms that promote the construction of new hotels and other types of tourist accommodation should be pursued. Already, the authorities have simplified the process for the licensing of tourism facilities. Over the past decade, such licenses have been fully integrated with other construction and land use permit procedures and the volume of required documentation reduced.

The sluggish supply response to the boom in tourism demand may reflect policy settings that reduce the availability of relevant service professionals. Increasing the supply of engineering professionals has been identified as a priority for policymakers given the prospect of shortages. Nevertheless, at present, there are tight restrictions on the characteristics of professionals that can undertake engineering and other constructionrelated activities. Only engineers and architects registered in the respective professional associations are able to undertake engineering projects and architecture plans. In some cases, professionals must have a minimum number of years of experience to perform these tasks. Instead of retaining reserved activities for these professionals, regulations should be revised to focus more on outputs, such as quality standards for building works (OECD, $2018 \mathrm{c}$ ). This would open up construction-related services to a broader range of providers, helping to ensure the supply of new construction keeps up with demand.

\section{Digital networks}

The standard of digital infrastructure is also increasingly important to firms accessing overseas markets. This is partly through its role in enabling information exchange and participation in e-commerce platforms. More generally, good digital network access allows firms to implement productivity-enhancing technologies into their production process that enhance cost competitiveness.

Portugal has good quality digital infrastructure compared with most OECD countries. Broadband is available to households throughout the country and a high proportion of enterprises have subscriptions to fast broadband (Figure 20, Panel A). Strong investment in the digital network over the past decade partly reflects the national regulatory authority decision to open access to the ducts and poles of Portugal Telecom to private companies. In rural areas, government funding has played a larger role in improving access to digital infrastructure. 
The proportion of enterprises selling online is low given the high proportion that have fast broadband access (Figure 20, Panel B). The use of productivity enhancing technologies, such as cloud computing, is also low compared with most OECD countries (Figure 21). Low levels of digitalisation is especially the case in small and medium enterprises, both constraining the ability of such firms to trade on world markets and the efficiency with which they can integrate into the supply chains of larger Portuguese exporters.

Figure 20. Broadband access is widespread but not many firms sell online
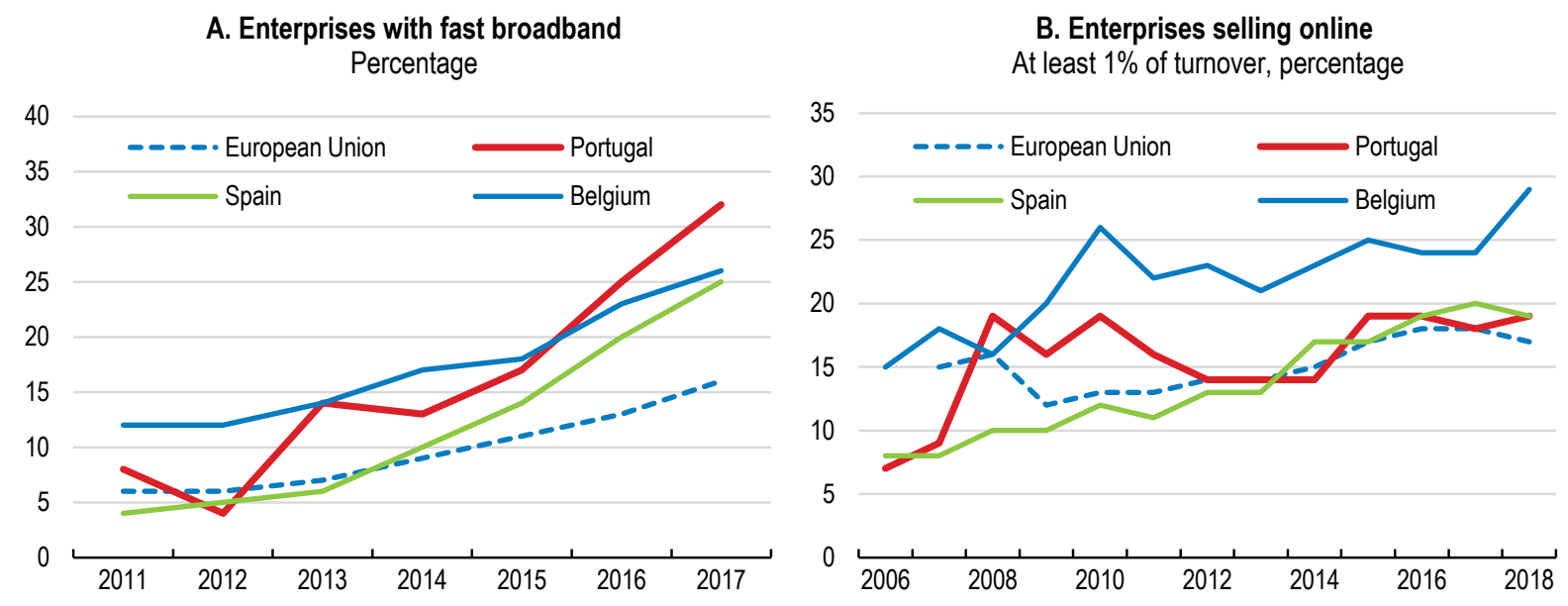

Note: In Panel A, "fast broadband" is defined as the contracted speed of an enterprises fastest internet connection being above $100 \mathrm{Mb} / \mathrm{s}$.

Source: OECD, ICT Access and Usage by Businesses (database).

In 2017, the government launched "Indústria 4.0", a national strategy for the digitisation of the economy. Included in the goals of the strategy are to increase the number of companies using e-commerce by 55\% between 2011 and 2020 and a rise in ICT exports of $25 \%$ over that time. The programme will allocate EUR 4.5 billion to associated programmes with around half the funding provided by EU Structural Funds.

Figure 21. Few businesses have integrated digital technologies into their operations

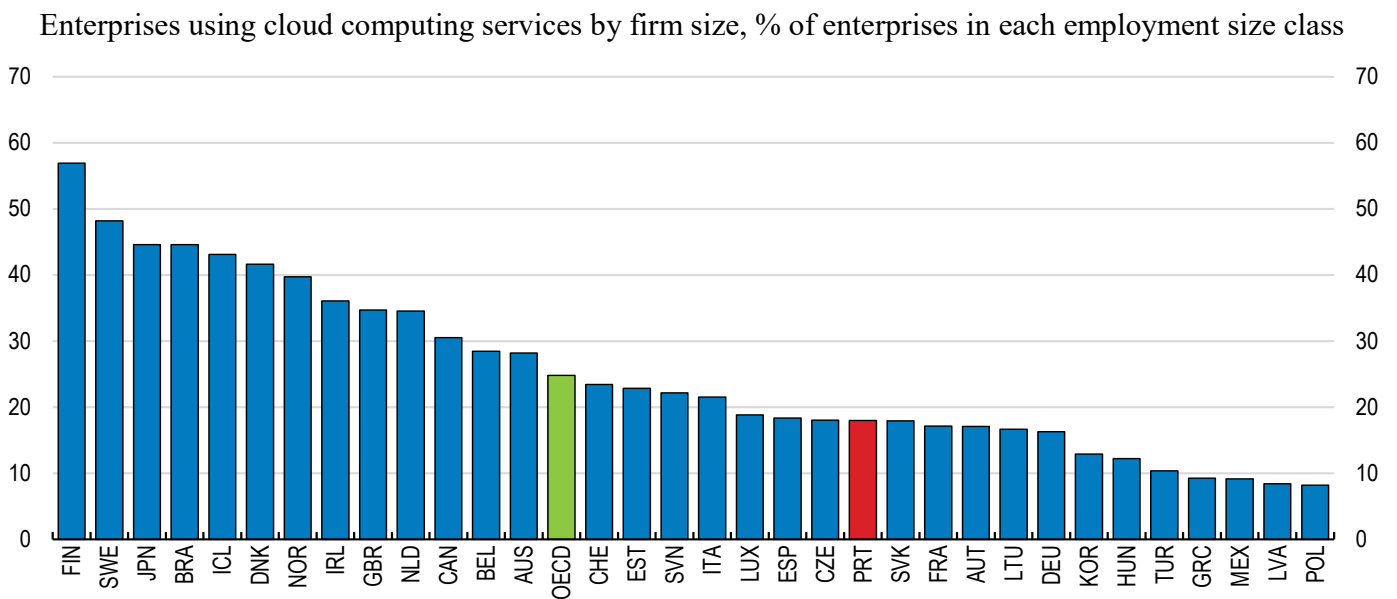

Source: OECD Digital Economy Outlook 2017. 
A constraint to expanding the penetration of new digital technologies is the low level of digital skills within the community. Just $50 \%$ of individuals possess basic or above basic digital skills, seven percentage points below the average across the European Union (Figure 22). Poor digital skills are particularly apparent in those over the age of 25 (OECD, 2018f). In response, the government has launched the National Initiative on Digital Competencies (INCoDe.2030). The programme aims to develop the digital skills of the population and to raise innovation in the digital sector (Box 4). Many of the activities under the programme are targeted to younger cohorts. Given the skills gap is particularly apparent for adults, the authorities should monitor the extent to which the programme is effectively targeting those with the lowest digital competencies (OECD, 2018f).

Figure 22. Only half the population have basic digital skills

Proportion of all individuals with basic or above basic digital skills, 2017

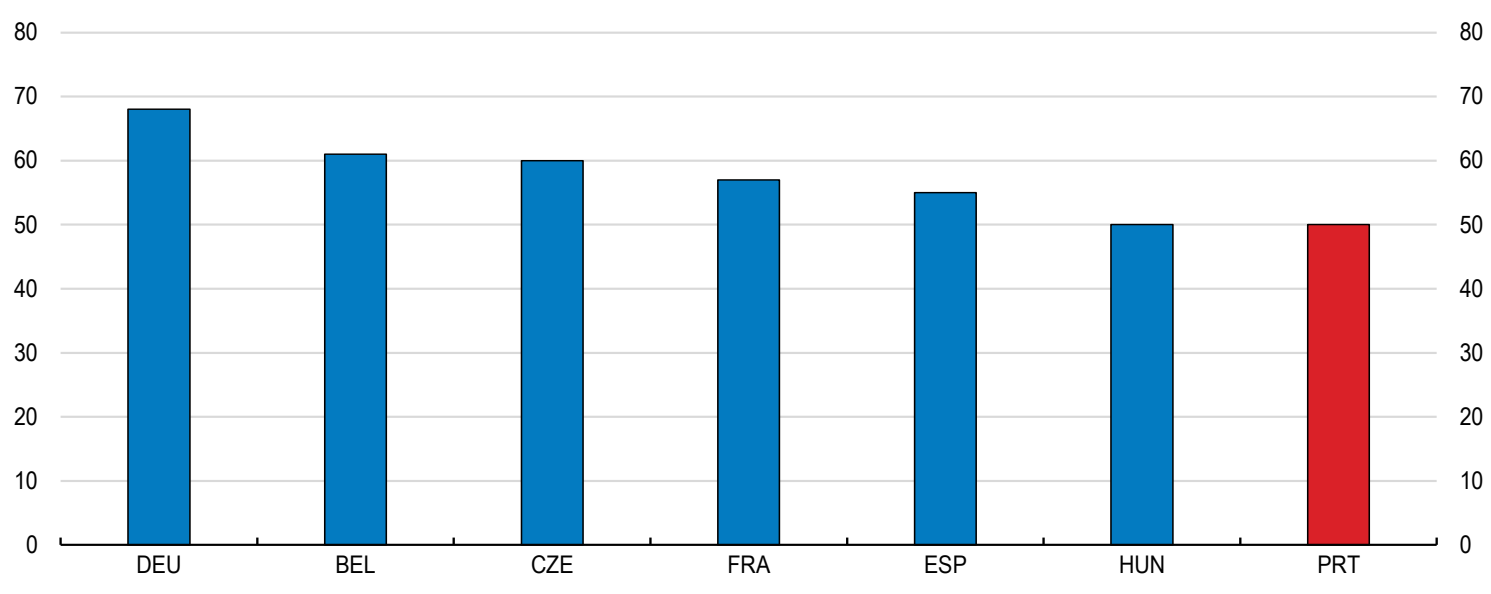

Source: Eurostat.

Box 4. Portuguese National Initiative on Digital Competencies 2030 (INCoDe.2030)

The Portuguese National Initiative on Digital Competencies 2030 (INCoDe.2030) aims to enhance and foster digital competencies. The initiative has a broad scope, starting with the promotion of digital inclusion and literacy, educating the young generations from an early age, qualifying the active population and specialising graduates for advanced digital jobs. The programme also aims to raise Portugal's level of innovation in the digital sphere.

The content of the programme takes a broad view of digital skills and includes aspects related to digital literacy, information processing, communication, digital content production skills and the ability to handle and manipulate data. Advanced communication networks and mobile systems, network hardware and software and cyber-physical systems like robotics are also covered.

The programme enables citizens to benchmark their level of digital skills on a dynamic framework based on the European initiative DigComp2.0, helping knowledge gaps to be identified. Specific programmes have also been targeted towards disenfranchised groups, who are able to use a freely accessible online training platform and are offered other training courses that focus on building digital competencies.

Source: (OECD, 2017c) 


\section{Promoting better skills and innovation in the business sector}

\section{Further providing the right skills}

Improving the performance of the export sector will also depend on achieving continued improvements in the quality and mix of workers' skills. Empirical evidence highlights a strong relationship between workers skills and trade, partly through influencing countries' integration into global value chains (Grundke et al., 2017). Given the expected decline in the working age population over coming years, ensuring that those in the labour force have the right skills to productively contribute is critical.

As detailed extensively in the 2017 OECD Economic Survey of Portugal, the stock of accumulated skills in the Portuguese population is low (OECD, 2017a). At the same time, demand for high skilled workers has been growing rapidly compared with other skill classes (OECD, 2018f). While school age enrolments are around the OECD average level, high drop-out rates and frequent grade repetition compound a legacy of low skill levels. In 2017, over half of Portuguese adults aged 25 to 64 had not completed upper secondary education. The quality of education in the school system has been improving: student performance across the fields of science, mathematics and reading all rose faster than in the average OECD country between 2006 and 2015. By that time, the average score in the Programme for International Student Assessment (PISA) in each discipline was above the OECD average. This has partly owed to a sequence of reforms to education policy, including an increase in the duration of compulsory school from 9 to 12 years, the introduction of national evaluations of school quality and the expansion of vocational and educational training pathways in secondary schools.

As a result of these developments, younger cohorts of the Portuguese population are substantially more educated than those that are older (Figure 23). Moreover, educational attainment of older groups lags behind that in comparable countries; the attainment of both non-tertiary and tertiary education is below the average in the European Union.

Figure 23. The educational attainment of adults is lagging

Percentage of individuals that have completed education

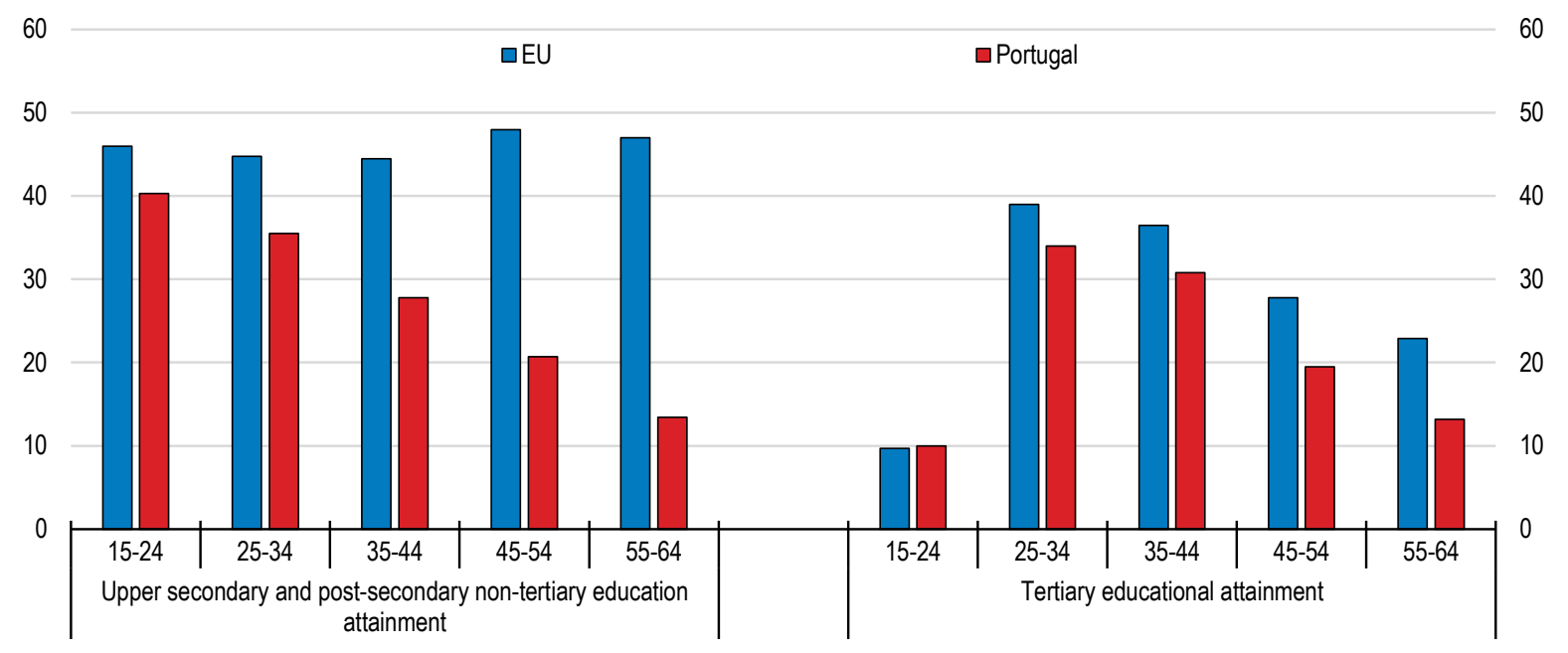

Source: Eurostat. 
Given the educational attainment of the population aged over 24 is lagging, adult education pathways are critical. Nevertheless, participation rates of 25-64 year olds in adult learning is slightly below the EU average and has shown no sign of improvement since 2011 (Figure 24). Participation rates of those with initially low levels of educational attainment are particularly modest, with the gap between the participation of the high-skilled and lowskilled larger than the EU average (OECD, 2018f). As digitalisation further skews labour demand towards high-skilled activities, this situation threatens to exacerbate the already high levels of inequality that exist in Portugal.

Figure 24. Participation in lifelong learning opportunities is low

Participation rate, percentage

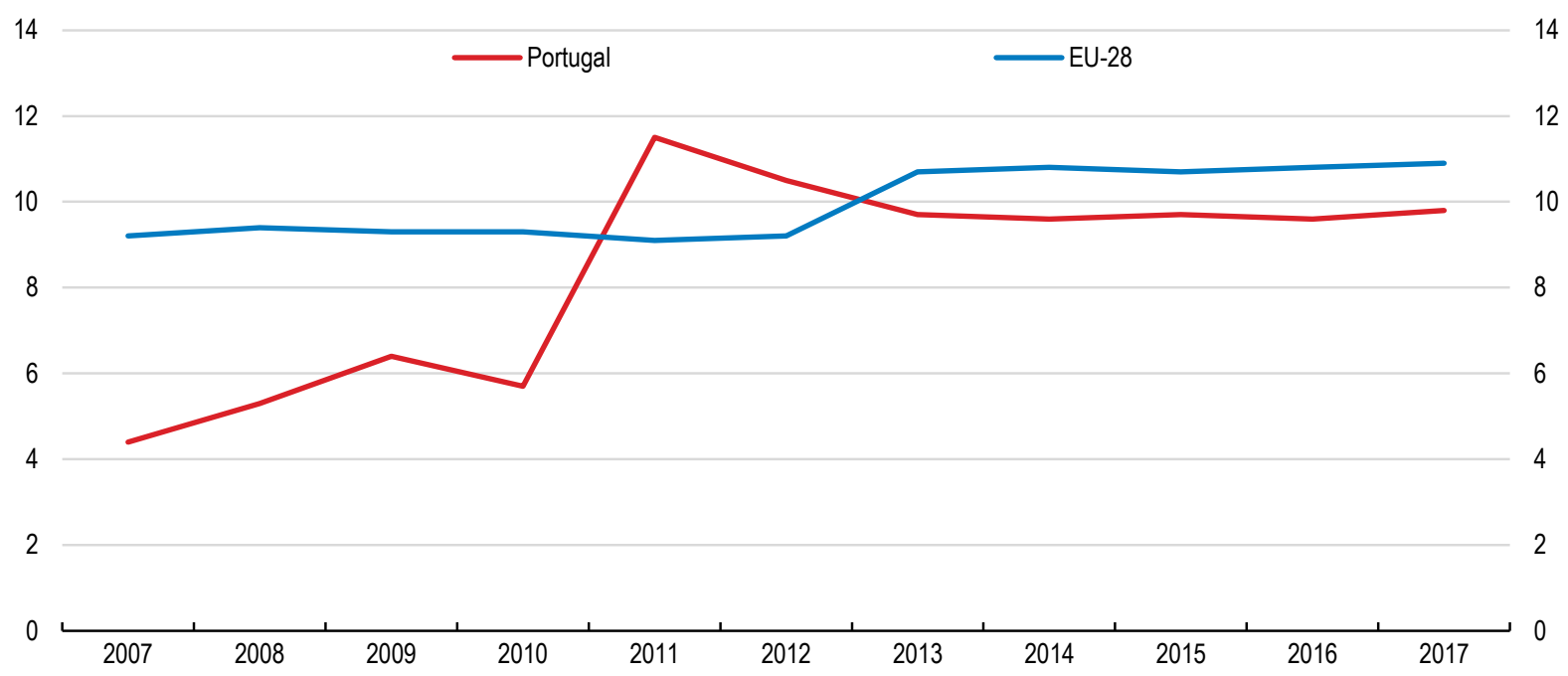

Source: Eurostat.

To improve both the skill profile and the inclusiveness of the economy, lifelong learning programmes should be better targeted towards the low-skilled. To be successful, this requires overcoming the motivational barriers of some low-skilled workers. In 2018, the OECD published guidance on the implementation of a skills strategy for strengthening the adult-learning system (OECD, 2018f). This emphasised useful approaches for overcoming this challenge, including the provision of better information on educational returns and tailoring information to the low-skilled population. However, to do this, better quality data about the skills of the adult population and the returns to different types of skills are needed. There may also be scope for new measures that better enable participation in learning activities, such as statutory education and training leave. This type of leave can be important for ensuring that a lack of time is not a barrier to adult learning. For this reason, it is offered in most OECD countries with many providing compensation for learners and employers alongside statutory leave (OECD, 2018f).

At the same time, there is a need for continuing to ensure that the supply of adult education programmes reflects labour market demand. It is not just a matter of increasing skills, but ensuring that the skills that will be required by the business sector in coming years are those that are being accumulated. There is significant scope in Portugal to boost the mechanisms for anticipating future skill needs and better aligning the supply of adult learning programmes to the needs of the labour market (OECD, 2018f). While such tools have been 
developed for planning the content of secondary-level vocational education and training courses, they should be introduced for planning vocational education offerings for adults.

One of the consequences of low participation in adult training of those in employment is weak managerial skills in Portuguese businesses. Such competencies are important for the export sector given that the ability to re-configure production processes to cater to new markets and value chains depends on the managerial skills in a firm. Compared with some other European economies, the degree of professional management in the business sector is low (Figure 25). Past work estimates that moving from the distribution of manager education in Portugal to that of the US would raise aggregate productivity by about $20 \%$ (Queiró, 2016). Furthermore, weak managerial capacity is found to contribute to the high share of small firms in Portugal relative to the US.

Figure 25. Professional management in the business sector is relatively rare Reliance on professional management index (7=highest), 2018

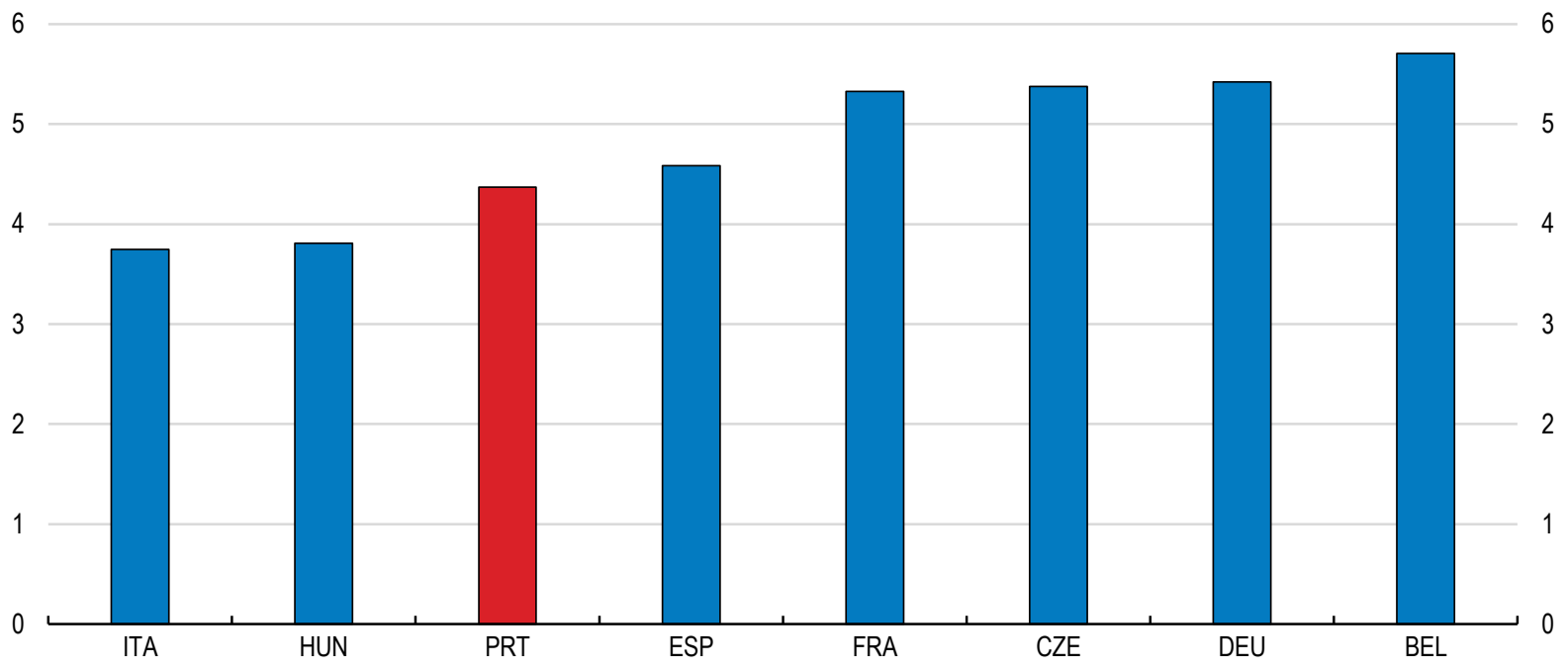

Note: The metric is based on answers to the question: in your country, who holds senior management positions ( $1=$ usually relatives or friends without regard to merit; $7=$ mostly professional managers chosen for merit and qualifications).

Source: World Economic Forum.

\section{Boosting innovation in the export sector}

Innovation policy settings need to support Portuguese exporters moving into new markets and continuing to develop products with a higher content of value added. There is evidence of strong gains in the quality of Portuguese manufacturing exports over the past decade compared to other European countries such as France, Germany, Italy and Spain (Box 5). Nevertheless, the level of export quality across most sectors remains low compared to these other countries. Furthermore, Portugal's manufacturing exports are in the mature phase of their life cycle compared to many other OECD countries (Figure 26), increasing the importance of innovation to sustain the future export performance of the economy. 


\section{Box 5. Estimates of the quality of manufacturing exports}

Recent work in the Bank of Italy used a methodology outlined by (Khandelwal, Schott and Wei, 2013) to produce estimates of the quality of manufacturing exports over time for several EU countries (Bugamelli et al., 2017). Using data at the HS-6 digit product level from CEPII-BACI, they estimate an export quality parameter that is assumed to be a demand shifter in a constant elasticity of substitution demand function (for further details, see (Bugamelli et al., 2017). That is, the estimated parameter explains differences in the quantity of a product sold in a given destination country holding prices constant.

The results highlight consistent improvements in the quality of Portuguese exports over the 1999-15 period (Table 2). Compared to France, Germany, Italy and Spain, the quality improvements in Portugal were particularly apparent in the 2007-15 period. These estimates reflect both the changes in the quality of a single product and the reallocation of exported volumes across products with different quality levels.

Table 2. Estimates of export quality

\begin{tabular}{lccccc}
\hline \% change & FRA & DEU & ITA & ESP & PRT \\
\hline $1999-2007$ & 2.3 & 3.1 & 3.4 & 3.2 & 2.9 \\
$2007-10$ & -3.2 & -0.9 & -2.7 & -2.5 & 0.8 \\
$2010-15$ & -1.4 & 0.3 & 0.6 & 0.7 & 0.7 \\
\hline
\end{tabular}

Source: Bugamelli et al., 2017, unreported estimates.

The sensitivity of export quantities to the improvements in export quality are investigated through the estimation of country-specific regressions. The results suggest that the improvement in export quality was positively associated with export quantity (confirming the product-level results documented in Box 2). However, the estimated elasticity of exports to quality is smaller than unity, while the (negative) coefficient on the export price term is well above unity (Table 2). This indicates that the positive effects of quality improvements on exports could be countervailed by an equivalent percentage point increase in Portuguese export prices.

Table 3. Regression results (Dependent variable = export quantity)

\begin{tabular}{|c|c|c|c|c|c|}
\hline & FRA & DEU & ITA & ESP & PRT \\
\hline $\begin{array}{l}\text { Export } \\
\text { quality }\end{array}$ & $\begin{array}{c}0.46^{* * * *} \\
(0.01)\end{array}$ & $\begin{array}{c}0.38^{* * *} \\
(0.008)\end{array}$ & $\begin{array}{l}0.45^{* * *} \\
(0.008)\end{array}$ & $\begin{array}{c}0.51^{* * * *} \\
(0.011)\end{array}$ & $\begin{array}{c}0.58 * * * \\
(0.02)\end{array}$ \\
\hline $\begin{array}{l}\text { Export } \\
\text { prices }\end{array}$ & $\begin{array}{c}-1.18^{* * *} \\
(0.01)\end{array}$ & $\begin{array}{c}-1.14 * * * \\
(0.008)\end{array}$ & $\begin{array}{l}-1.17 * * * \\
(0.011)\end{array}$ & $\begin{array}{c}-1.23 * * * \\
(0.014)\end{array}$ & $\begin{array}{c}-1.26 * * * \\
(0.029)\end{array}$ \\
\hline Obs. & 1462233 & 2121611 & 1735112 & 1046231 & 298201 \\
\hline
\end{tabular}

Notes: Both the dependent and independent variables are in log-difference form. The regressions are estimated over the 1999-2015 period and include both product-time and destination-time fixed effects to control for changes in demand conditions that are common across products or destinations. Standard errors are in parentheses and $*$ signifies $\mathrm{p}$-value $<0.05,{ }^{*} \mathrm{p}<0.01, * * * \mathrm{p}<0.001$.

Source: Bugamelli et al., 2017, unreported estimates. 
Figure 26. The export product mix is relatively mature

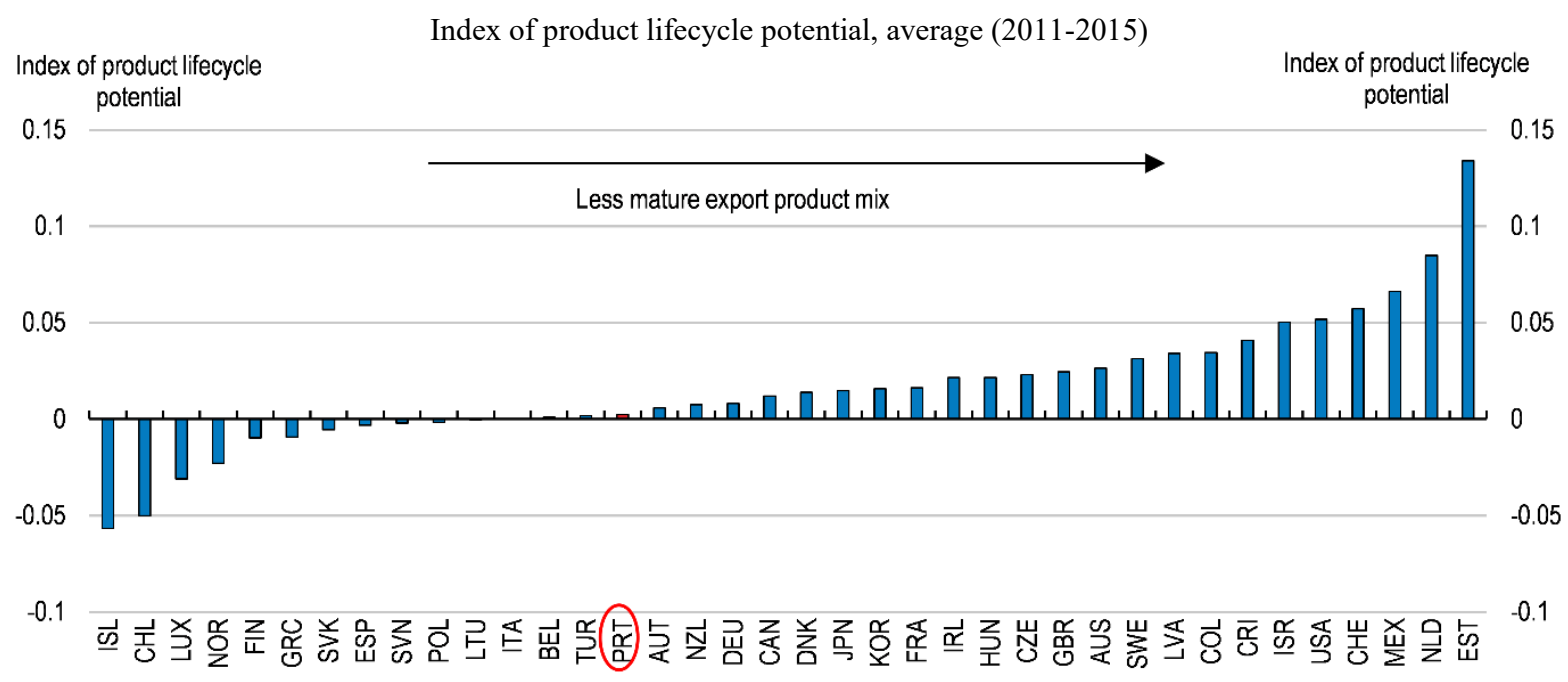

Note: The index is based on the analysis of dynamic comparative advantage by (Audretsch, Sanders and Zhang, 2012[37]), with the semi-elasticity of each export product with respect to time weighted according to the export shares of the product in a country's total exports. For further details, see Araujo, Chalaux and Haugh (2018). Source: Araujo, Chalaux and Haugh (2018).

Portugal's business sector spends relatively little in the generation of knowledge-based capital. Both business research and development (as a percentage of GDP) and the number of patents (per capita) are in the lowest quadrant across OECD countries (Figure 27). This partly reflects the dominance of SMEs in the economy (OECD, 2018g). While many SMEs may be unlikely to develop radical innovations, performing research activity is important for their ability to demystify new technologies being developed abroad and adapt them to suit their production processes. Indeed, empirical evidence highlights the significant role of R\&D capacity in the domestic business sector for technological transfer and crosscountry productivity convergence more broadly (Griffith, Redding and Reenen, 2004).

Figure 27. Research intensity and innovation output in the business sector are low

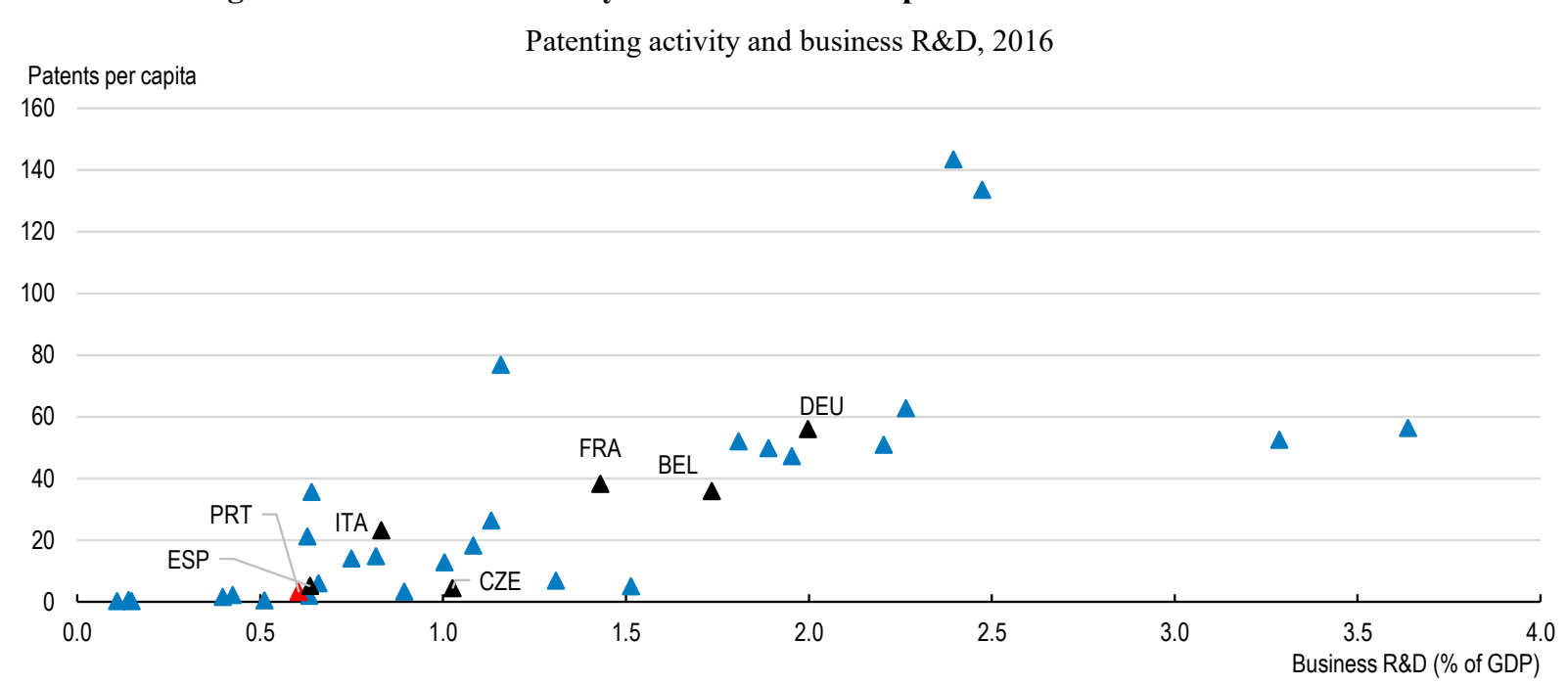

Note: Business R\&D data for Australia, New Zealand and Switzerland are for 2015.

Source: OECD, United Nations. 
Smaller firms can build innovation capacity through collaboration with external entities possessing the advanced machinery or skilled personnel to engage with the technologies and organisational processes at the technological frontier. While collaborative projects financed by EU funds have been increasing in the last few years, Portuguese firms are less likely to collaborate in innovative activities than their EU counterparts (Figure 28, Panel A). This is due to particularly low collaborative activities of those smaller and mediumsized firms that could accrue substantial benefits (Figure 28, Panel B).

Figure 28. Collaborative research activities are limited, especially for small firms

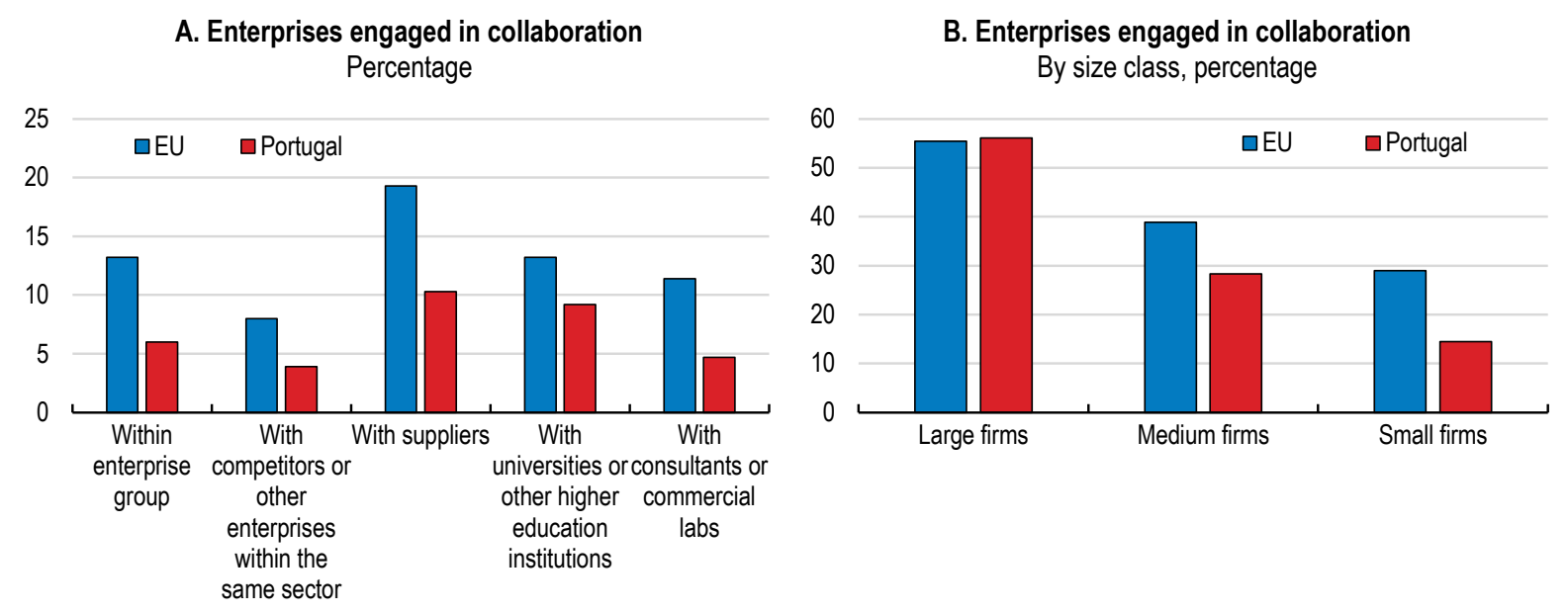

Source: Eurostat.

The government has established a variety of intermediary organisations (technology transfer offices, technology centres, science and technology parks, incubators and clusters), partly funded through EU funds. The efficacy of the various intermediary institutions should be carefully evaluated and ongoing government funding allocated to those that have been shown to be particularly effective. In 2017, the government launched the Programa Interface, which includes multi-annual financial support for selected intermediary organisations including technology centres, clusters and collaborative laboratories (Box 6). As recommended in the 2018 OECD Review of Higher Education, Research and Innovation, this funding should be maintained on a continuous basis for intermediary organisations that successfully fulfil the objectives announced in their development plans.

\section{Box 6. Fostering innovation collaboration through Programa Interface}

Launched in 2017, the ongoing Programa Interface aims to improve links between scientific knowledge and business innovation through fostering collaborative activities between universities, research and technology organisations and companies. The programme includes four main initiatives:

- Technology and Interface Centres - 28 such centres have been certified, with EU funds being directed to support companies' collaborations with these centres in key domains such as digitisation, circular economy or energy efficiency, as well as promoting scientific and qualified employment and R\&D projects within businesses; 
- Clusters - 20 sectoral clusters have been recognised in a variety of sectors such as mineral resources, architecture, engineering and construction, sustainability, health and footwear. The clusters aim to promote internationalisation and knowledge sharing among companies, higher education and research institutions.

- Collaborative Laboratories - 21 "CoLabs" have been identified that define and implement research and innovation agendas in specific topic areas that can create economic and social value. Various entities are engaged in the CoLabs including companies, higher education institutions, intermediate and interface institutions, technological centres, business associations and other relevant partners. Selected topics include food and smart farming, construction sustainability, healthcare, cyber security and poverty and social protection;

- Clubs of Suppliers - aims at promoting companies, especially SMEs, to participate in international value chains. For instance, this may occur by supporting a firm that already cooperates with a specific multinational to jointly expand and supply other branches.

There is also scope for a more focused approach to promoting innovation collaboration by small and medium enterprises. One of the major impediments to the participation of smaller firms may be a lack of understanding of how to engage in such collaborative activities. Research institutions, such as universities and polytechnics, should thus focus on providing simple short-term collaborative activity offerings (e.g. updating ICT capacity in a small business) that can lead to a longer term relationship and more transformational projects for the firm.

In Ireland, one approach by research centres to increase the involvement of small firms in collaborative activities has been to gather a group of them together to participate in a "grand challenge" research project in which they all have a common interest (OECD, 2018h). Such an approach reduces the investment needed in the project by any individual firm, making it more feasible and attractive for them to participate. In other countries, including the United States, the United Kingdom and several Latin American countries, specific regionally-based institutions have been set up to provide small and medium enterprises easy access to resources that help them upgrade their innovation capabilities such as relevant information, expertise and equipment (OECD, 2018g). 


\section{Policy recommendations for further promoting export performance}

\section{Improving the framework policies for high-potential businesses}

Key recommendations

- Simplify the tax system by reducing the use of special provisions (e.g. tax exemptions, special rates) and ambiguity in the tax language.

Other recommendations

- Open reserved activities for certain professions to competition from other professions, such as the exclusive rights of customs brokers to represent firms to relevant authorities.

\section{Ensure domestic infrastructure promotes better export performance}

Key recommendations

- In awarding port concessions, take into account the price that bidders will charge port users in addition to other criteria.

- Ensure that port concession contracts specify a minimum level of investment by the operator and do not renew concessions without opening a new public tender.

\section{Other recommendations}

- Abolish regulations that restrict the ability of port authorities to license multiple private operators for some port services.

\section{Promoting better skills and innovation in the business sector}

Key recommendations

- Better target lifelong learning opportunities to the low-skilled, including by collecting information on the private returns to skills and making it publicly available.

\section{Other recommendations}

- Ensure that adults are targeted by programmes aiming to enhance digital skills.

- Introduce tools to ensure vocational education curricula for adult education reflect labour market needs.

- Continue to support intermediary organisations that focus on fostering innovation collaboration for small and medium enterprises. 


\section{References}

Adamczyk, P. and B. Westmore (2019), "Factors behind Portugal's recent export performance", OECD Economics Department Working Paper, forthcoming.

Ahlfeldt, G., B. Franke and W. Maennig (2015), "Terrorism and International Tourism: The Case of Germany", Bd, pp. 235-1.

Amador, J. and S. Cabral (2008), "The Portuguese export performance in perspective: a constant market share analysis", Bank of Portugal Economic Bulletin, Vol. Autumn.

Amador, J., B. Ringstad and S. Cabral (2018), A portrait of Portuguese international traders of nontourism services, Bank of Portugal.

Amador, J. and A. Soares (2014), "Competition in the Portuguese economy: estimated price-cost margins under imperfect labour markets", Working Paper Series, No. 1751, European Central Bank, Frankfurt, http://dx.doi.org/10.2866/499073.

Amador, J. and A. Soares (2012), "Competition in the Portuguese economy: an overview of classical indicators", No. 8, Banco de Portugal, Lisbon, http://www.bportugal.pt.

Araújo, S., T. Chalaux and D. Haugh (2018), "Who's in your export market? The changing pattern of competition in world trade", OECD Economics Department Working Papers, No. 1526. OECD Publishing, Paris.

Araújo, L. (2017), "Portuguese tourism strategy 2027: leading the tourism of the future", Worldwide Hospitality and Tourism Themes, Vol. 9/6, http://dx.doi.org/10.1108/WHATT-09-2017-0052.

Arnold, J. and N. Barbosa (2015), "Structural policies and productivity: Evidence from Portuguese firms", OECD Economics Department Working Papers, No. 1259, OECD Publishing, Paris, http://dx.doi.org/10.1787/5jrw21mfp4kd-en.

Audretsch, D., M. Sanders and L. Zhang (2012), "How exports matter: trade patterns over development stages", Discussion Paper, No. 8815, Centre for Economic Policy Research, London, http://www.cepr.org.

Bank of Portugal (2018a), Economic Bulletin - October 2018, Bank of Portugal, Lisbon, http://www.bportugal.pt.

Bank of Portugal (2018b), Financial Stability Report, Bank of Portugal, Lisbon.

Bank of Portugal (2016), "Economic Bulletin - October 2016".

Bergner, S. et al. (2017), “The Use of SME Tax Incentives in the European Union”, ZEW Discussion Paper, No. 17-006, Centre for European Economic Research, http://dx.doi.org/10.2139/ssrn.2910339.

Berkowitz, J. and M. White (2004), "Bankruptcy and Small Firms' Access to Credit", RAND Journal of Economics, Vol. 35.

Borrego, A. et al. (2015), "Tax professionals' perception of tax system complexity: some preliminary empirical evidence from Portugal”, eJournal of Tax Research, Vol. 13/1, pp. 338-360.

Bugamelli, M. et al. (2017), "Back on track? A macro-micro narrative of Italian exports", Occasional Papers, No. 399, Banca d'Italia. 
Correia, A. and A. Gouveia (2016), "What Determines Firm-level Export Capacity? Evidence from Portuguese firms", No. 57, Gabinete de Estratégia e Estudos.

Dalum, B., K. Laursen and G. Villumsen (1998), "Structural change in OECD export specialisation patterns: de-specialisation and 'stickiness'", International Review of Applied Economics, Vol. 12/3, http://dx.doi.org/10.1080/02692179800000017.

Deloitte (2017), Uma visão global: Observatório da Competitividade Fiscal, Deloitte Touche Tohmatsu.

Economist Intelligence Unit (2018), “Country Report: Portugal”, http://www.eiu.com.

Égert, B. and P. Gal (2018), "The quantification of structural reforms: Introducing country-specific policy effects", OECD Economics Department Working Papers, No. 1487, OECD Publishing, Paris, http://dx.doi.org/10.1787/885727c3-en.

Égert, B. and I. Wanner (2016), "Regulations in services sectors and their impact on downstream industries: The OECD 2013 Regimpact Indicator", OECD Economics Department Working Papers, No. 1303, OECD Publishing, Paris, http://dx.doi.org/10.1787/5jlwz7kz39q8-en.

Esteves, P. and A. Rua (2015), "Is there a role for domestic demand pressure on export performance?", Empirical Economics, http://dx.doi.org/10.1007/s00181-014-0908-5.

European Central Bank (2018), Survey on the access to finance of enterprises in the euro areaOctober 2017 to March 2018, European Central Bank, June 2018.

European Commission (2018), Country Report Portugal 2018, European Commission, Brussels.

Gabinete da Secretária de Estado Adjunta e da Modernização Administrativa (2017), Programa Simplex+: Resultados do estudo de impacto económico, Gabinete da Secretária de Estado Adjunta e da Modernização Administrativa, Lisbon.

Griffith, R., S. Redding and J. Reenen (2004), "Mapping the two faces of R\&amp;D: productivity growth in a panel of OECD industries", Review of Economics and Statistics, Vol. 86/4, http://dx.doi.org/10.1162/0034653043125194.

Grundke, R. et al. (2017), "Having the right mix: The role of skill bundles for comparative advantage and industry performance in GVCs", OECD Science, Technology and Industry Working Papers, No. 2017/03, OECD Publishing, Paris, http://dx.doi.org/10.1787/892a4787-en.

IMF (2017), "Portugal: 2017 Article IV Consultation-Press Release; Staff Report; and Statement by the Executive Director for Portugal; IMF Country Report No. 17/278; August 16, 2017”, http://www.imf.org.

Khandelwal, A., P. Schott and S. Wei (2013), "Trade liberalization and embedded institutional reform: Evidence from Chinese exporters", American Economic Review, Vol. 103/6, http://dx.doi.org/10.1257/aer.103.6.2169.

Lee, N., H. Sameen and M. Cowling (2015), "Access to finance for innovative SMEs since the financial crisis", Research Policy, Vol. 44, pp. 370-380, http://dx.doi.org/10.1016/j.respol.2014.09.008.

Martins, F. (2016), "How the Portuguese firms adjusted to the economic and financial crisis: main shocks and channels of adjustment", Economic Bulletin and Financial Stability Report Articles and Banco de Portugal Economic Studies.

Martins, F. (2016), "How the Portuguese firms adjusted to the economic and financial crisis: main shocks and channels of adjustment", Bank of Portugal Economic Studies, Vol. 2. 
McGuinness, G. and T. Hogan (2016), "Bank credit and trade credit: Evidence from SMEs over the financial crisis", International Small Business Journal: Researching Entrepreneurship, Vol. 34/4, http://dx.doi.org/10.1177/0266242614558314.

Morin, M. and C. Schwellnus (2014), "An Update of the OECD International Trade Equations", OECD Economics Department Working Papers, No. 1129, OECD Publishing, Paris, http://dx.doi.org/10.1787/5jz2bxbkrxmv-en.

OECD (2018a), OECD Compendium of Productivity Indicators 2018, OECD Publishing, Paris, http://dx.doi.org/10.1787/pdtvy-2018-en.

OECD (2018b), OECD Review of National Research and Development Tax Incentives and Estimates of Research and Development Tax Subsidy Rates, OECD Publishing, Paris.

OECD (2018c), OECD Competition Assessment Reviews: Portugal: Volume II - Self-Regulated Professions, OECD Competition Assessment Reviews, OECD Publishing, Paris, http://dx.doi.org/10.1787/9789264300606-en.

OECD (2018d), Financing SMEs and Entrepreneurs, OECD Publishing, Paris.

OECD (2018e), OECD Competition Assessment Reviews Portugal: Volume I- Inland and Maritime Transport and Ports, OECD Publishing, Paris.

OECD (2018f), Skills Strategy Implementation Guidance for Portugal: Strengthening the AdultLearning System, OECD Skills Studies, OECD Publishing, Paris, http://dx.doi.org/10.1787/9789264298705-en.

OECD (2018g), OECD Review of Higher Education, Research and Innovation: Portugal, OECD Publishing, Paris.

OECD (2018h), OECD Economic Surveys: Ireland 2018, OECD Publishing, Paris, http://dx.doi.org/10.1787/eco_surveys-irl-2018-en.

OECD (2017a), OECD Economic Surveys: Portugal 2017, OECD Publishing, Paris.

OECD (2017b), Getting Infrastructure Right: A framework for better governance, OECD Publishing, Paris, http://dx.doi.org/10.1787/9789264272453-en.

OECD (2017c), Initial Insights from the Going Digital Policy Framework Questionnaire, Directorate for Science, Technology and Innovation Committee on Digital Economy Policy.

OECD (2015), The Future of Productivity, OECD Publishing, Paris, http://dx.doi.org/10.1787/9789264248533-en.

OECD (2010), OECD Tax Policy Studies Tax Policy Reform and Economic Growth, OECD Publishing, Paris.

Queiró, F. (2016), “The Effect of Manager Education on Firm Growth”, mimeo.

Statistics Portugal (2017), Transport and Communications Statistics 2016, Statistics Portugal, Lisbon, http://www.ine.pt. 